\title{
CHALLENGES OF INTERNATIONALLY EDUCATED FILIPINO SOCIAL WORK \\ PROFESSIONALS: IMPLICATIONS FOR SOCIAL WORK PRACTICE IN CANADA
}

by

Roshena Grace Hernandez, BSW, Centro Escolar University, 2005

\author{
An MRP \\ presented to Ryerson University \\ in partial fulfillment of the \\ requirements for the degree of \\ Master of Social Work \\ in the Program of \\ Social Work
}

Toronto, Ontario, Canada 2016

(C) Roshena Grace Hernandez 2016 


\section{AUTHOR'S DECLARATION FOR ELECTRONIC SUBMISSION OF A MRP}

I hereby declare that I am the sole author of this MRP. This is a true copy of the MRP, including any required final revisions.

I authorize Ryerson University to lend this MRP to other institutions or individuals for the purpose of scholarly research

I further authorize Ryerson University to reproduce this MRP by photocopying or by other means, in total or in part, at the request of other institutions or individuals for the purpose of scholarly research.

I understand that my MRP may be made electronically available to the public. 


\author{
ABSTRACT \\ Challenges of Internationally Educated Filipino Social Work Professionals: Implications \\ for Social Work Practice in Canada \\ Master of Social Work, 2016 \\ Roshena Grace Hernandez \\ Program of Social Work, \\ Ryerson University
}

This study explores the lived experiences of internationally educated, Filipino social work professionals during their integration into the Canadian labour force. The need to pursue this topic stemmed from the recognition of the barriers faced by internationally educated Social Work professionals as they embark on a social work career in Canada. This phenomenological, qualitative research utilized one-on-one in-depth interviews with four Filipino social work professionals who obtained education and professional experience in the Philippines. Participants have all resided within Canada for five to ten years, have had their credentials assessed, and have been registered with Ontario's regulatory body. As an insider of this particular group, the researcher aims to identify the challenges they encounter to pursuing a Canadian social work career, which are limited by systemic barriers; a lack of connections; personal barriers; and a lack of knowledge regarding Canadian legislation and the social welfare system. 


\section{TABLE OF CONTENTS}

Chapter 1: Introduction

Page 1

Chapter 2: Theoretical Framework

Page 4

Chapter 3: Literature Review

Page 7

Chapter 4: Research Design

Page 19

Chapter 5: Findings

Page 28

Chapter 6: Implications and Conclusions

Page 53

Appendices

Page 56

References

Page 63 


\section{LIST OF APPENDICES}

Appendix A - Consent Agreement

Page 56

Appendix B - Confirmation of Agreement

Page 59

Appendix C-Recruitment Advertisement

Page 60

Appendix D - Ethics Certificate

Page 61

Appendix E - Interview Guide

Page 62 


\section{CHAPTER 1. INTRODUCTION}

Canada is considered a country laden with appealing opportunities for foreign-trained individuals, resulting in an immigration influx during the past decade (Lusis \& Bauder, \& CERIS, 2008; Novak \& Chen, 2013). This appeal to professionals includes social work, as this profession is listed as one of those expected to continue to grow in Canada (Pullen- Sansfaçon, Brown \& Graham, 2012). According to Employment Ontario's employment prospect rating for 2013 - 2017, the growing social service needs in the province have increased the labour demand for social workers by twenty percent as compared to 2001 (Service Canada, 2011).

Due to limited programs and services available to support internationally educated professionals in transitioning into the Canadian work force, foreign-trained social workers are marginalized during the hiring process for they are unable to meet the "Canadian experience" hiring requirements present in most social work jobs (Sakamoto, Jeyapal, \& Bhuyan, 2013). The lack of documentation on the lived realities of internationally educated Filipino social work professionals, as well as the unsubstantial aid to address the difficulties they encounter, were major factors in my motivation to conduct this study. This researcher, a Filipino native female, attended an accredited university in the Philippines for four years, where she obtained a BSW and then worked for three years in her home country as a social worker. In 2012, she immigrated to Canada and faced multiple barriers to employment. She submitted up to 50 resumes daily and only received 4 interviews in 1.5 years. Post-interview comments highlighted her lack of "Canadian experience", "Canadian education", and "immersion in Canadian society." Through individual, in-depth interviews this qualitative phenomenological study explores the narratives of

four internationally educated Filipino social work professionals in order to better understand the 
challenges they face and how they make sense of their lived realities. The study also aims to understand how these social work professionals successfully enter the labour market and deconstruct the concept of "Canadian experience".

\section{Problem Statement}

Gray (2007) states that existing difficulties and problems faced by an individual or group are the basis for conducting a study. As an internationally-educated Filipino social worker, I consider myself as an insider of this particular group which I believe is consistently marginalized as they struggle on a journey toward successful integration into the Canadian labour market. The realities of these foreign-trained social workers must be unveiled.

Potts and Brown (2005) argue that the ideal individual to conduct a study of a certain phenomenon is the person who encounters this issue themselves. The authors also suggest that as an anti-oppressive researcher, you are "looking for meaning, for understanding, for the power to change" (p. 261). Given that the power to inform readers to affect change relies upon the hand of the researcher, as an insider conducting anti-racist research, this requires the balancing of one's insider and outsider role in the study. With this balancing act, Humphrey (2007) identifies that there is a paradox involved with being an insider, particularly around the possibility of jeopardizing the research by including personal views which might bias the study. To address this limitation, Humphrey (2007) suggests researchers raise their consciousness around the notion of the "insider-outsider hyphen" and to utilize "reflexivity" in order to protect the research and the study (p. 3). Similarly, in this study, to provide more reliable results, I will also engage in reflexivity as I use my professional social work experiences as tools to conduct the study.

Internationally-trained, Filipino social work professionals face significant barriers to employment in Canada, yet very little is known about their experiences and how they impact 
their lives (Pullen-Sansfaçon, Brown, Graham, \& Dumais-Michaud, 2013). This study aims to fill this gap in social work literature and to identify the challenges faced by foreign-trained Filipino social workers in Canada. This research will also highlight and break down their experiences as they search for employment, by privileging the narratives of their lived experiences as empirical data in order to understand their experiences from their own perspectives. The exploration of this issue will provide awareness of the realities encountered by internationally-educated Filipino social work professionals in Canada to policymakers, politicians, immigration settlement agencies, social work programs in post-secondary institutions, and other Filipinos considering to make Canada their future home.

This research hopes to influence social work agencies to evaluate, recognize, and accept the credentialing results of foreign-trained Filipino social workers by the Canadian Association of Social Workers as well as the licensing authority given to these Filipino social workers by the Ontario College of Social Workers and Social Services Workers. Further, in order to give these workers an equal chance to compete in the hiring process this area of study must be explored given the current lack of research on it. This study will seek to highlight the importance of government programs, immigration and settlement agencies, and social work agencies who create interventions to address the ongoing social problems such as racism and systemic barriers, language, and economic barriers encountered by Filipino social workers and other racialized professionals trying to make professional transitions into Canada. Ultimately, this study will utilize an anti-racist framework to analyze the oppressive experiences of social work professionals who are excluded from the Canadian labour market. The next section provides an extensive discussion of the anti-racist theoretical framework that has informed this study. 


\section{Chapter 2. Theoretical Framework}

This study was guided by anti-racism theory in order to examine the racial oppression experienced by Filipino social work professionals within the Canadian labour market (Dei, 1996; Pon, 2004; Pon, Gosine \& Phillips, 2011; Yee, Wong \& Janzacur, 2007). The use of anti-racism theory is essential to describing the presence of systemic racism in the Canadian labour market as it recognizes the inequity of rights and privileges between racialized job seekers and the dominant race (Yee et al., 2007). Anti-racism theory analyzes the systemic operation of racism by which racialized individuals (such as Filipino, foreign-trained social workers) are excluded from the labour market (Yee et al., 2007). Pon (2004) also confirms that anti-racism is a "proactive approach" to understanding the ongoing "structural inequities" and oppression of racialized groups (p.34). For instance, using an anti-racist lens, the non-recognition of the credentials of internationally-educated Filipino social work professionals can be viewed as overt systemic racism against racialized groups (Alboim, Finnie \& Meng, 2005; Davidson, 2007).

Mainstream Canadian employers utilize a native English accent as the default standard of communication, thus penalizing non-native English speaking applicants, explicitly 'othering' them (Davidson, 2007). These applicants are judged based on their verbal communication skills in relation to native English speakers as a means of evaluating their worth as professionals. Many Canadian employers view non-native English speakers as incompetent; a system that consistently degrades, devalues and demoralizes racialized and non-native English speakers (Gou, 2009). Anti-racism discourse critiques whiteness, which is the privileging of white cultural values, norms and practices (Pon, 2004; Dei 1996). It recognizes the privilege of Whiteness which in turn gives them power over racialized groups. White privilege and power judges 
everyone else based on a dominant, Eurocentric value system which leads directly to the 'othering' of racialized groups' identity and norms (Dei, 1996; Pon, 2004).

Anti-racist theory involves the "process of racialization" by which White individuals have privilege and power as they navigate a social system that reflects their personal beliefs (Yee et al., 2007, p.5). Thus, the issue of whiteness aggravates the vulnerability and oppression of foreign-educated social work professionals. As Filipino social work professionals attempt to secure employment in their field, the disparity of treatment between them and the dominant race in the labour market is becoming increasingly evident. Moreover, Dei (1996) argues that racialized groups are marginalized in a society where their knowledge and experiences are delegitimized. Further, foreign-trained social workers also have to navigate a social system in Canada that does not reflect or favour their race, employment goals and desires. These factors all work together to marginalize and oppress foreign-educated social work professionals.

Race shapes a person's self-identification and participation in their social environment (Pon, Gosine \& Phillips, 2011). In the context of mainstream social work agencies' values and the exclusion experienced by internationally educated professionals, Yee, Wong, and Janzacur (2007) state that "race can mediate people's understandings and perception of those experiences" (p. 6). Furthermore, they state that there are two levels of "differences between people's perception and understanding of these values" (Yee, Wong \& Janzacur, 2007, p. 6). The first level describes the notion that the values of mainstream social work agencies are in line with individuals from the dominant, White group. The second level describes how members of nonracialized groups "take for granted how their values are institutionally and socially supported by others in the community" as normative (p.6). In white-dominated Canada, there is a recurring theme of power, privilege and authority that plays into the hiring process. The racist and 
'othering' practice of requiring Canadian experience to secure a job is rooted in the prevailing ideation of white culture, and universalization of a dominant race's experience, which results in racial and labour discrimination of people of colour (Davidson, 2007; Grant, 2005; PullenSansfaçon et al., 2013; Novak \& Chen, 2013). The concept of Canadian experience in the employment recruitment process provides power to Canadian employers and allows them to legally discriminate against foreign-trained professionals.

Similarly, this study will utilize anti-racist theory as a framework for investigating how Filipino, foreign-trained social workers are penalized for having a value system which differs from the Eurocentric, White social work agenda. Further, it will utilize anti-racist theory to explore participants' interpretations of how race played a role in their journey to securing employment in Canada. This study will also examine the lived, social and economic realities of Filipino foreign-trained social workers whose values, work experiences, and education do not fit the dominant, White norm nor the social work agencies that are founded upon such values.

According to Pon (2009) "systemic and structural racism" remains prevalent in the Canadian society today. Young (2000) states that racism is a distinct form of oppression that marginalizes racialized groups and legitimizes the dominant race. Mainstream Canadian employers measure the competence of prospective employees based on the dominant white group's norms and values which devalues racialized applicants' human capital. The social realities of foreign-trained Filipino social workers are evidences of the systemic and structural racism inherent in Canada and specifically, in the Canadian labour market. As we explore the lived realities of this barrier to employment for foreign-born social workers, it is essential to break down the Eurocentric vision of what social work looks like in order to prioritize alternatives ways of knowing and helping. 


\section{CHAPTER 3. LITERATURE REVIEW}

Existing literature on the challenges faced by internationally-educated Filipino social work professionals in the Canadian labour market is very limited. It is not a subject which is of mainstream interest, and thus research on it is limited, but within anti-oppressive social work practice it is a key issue which must be explored. The following literature review will provide an overview of existing literature which explores the challenges faced by foreign-trained social workers, particularly Filipino social workers, in the Canadian labour market.

The research on this subject is quite limited overall, but through specific and detailed searches of multiple databases, some research was located. This research included thorough searches of both Ryerson University and York University's online database and libraries, as well as Google scholar. Keywords searched for included phrases such as: internationally educated social workers in Canada, immigrant social workers, barriers to employment search in Canada, challenges encountered by immigrant social workers, foreign credentials assessment for social workers, recognizing foreign-obtained credentials, and systemic barriers to integrate in the labour force. The resultant literature review contains publicly accessible documents that have information regarding the Government of Canada's pre-migration information for Internationally Educated Social Workers; the Canadian Association of Social Workers credentials assessment requirements and procedures for Internationally Educated Social Workers; and the Ontario Ministry of Training, Colleges and Universities’ Labour Market Information.

Three dominant themes emerged from the above sources. These included systemic barriers to employment (Alboim, Finnie \& Meng, 2005; Davidson, 2007; Lusis \& Bauder, 2008; Novak \& Chen, 2013), language barriers to employment (Davidson, 2007; Ngo \& Este, 2006; Sinacore, Mikhail, Kassan, \& Lerner, 2009), and economic barriers (Cheng, Spaling \& Song, 
2013; Ngo \& Este, 2006). These themes are considered the main stumbling blocks for foreigneducated Filipino social workers attempting to pursue social work careers in Canada.

\section{Systemic Barriers to Employment}

Canada's Immigration Act of 1976 was formulated around several goals, which include solidifying the economy, realizing social and cultural objectives, and achieving family reunification (Citizenship and Immigration Canada, 2006; Thobani, 2000). Previously, at the United Nations Convention in 1951, Canada committed itself to "international obligations" related to immigrants and refugees (Citizenship and Immigration Canada, 2006; Novak \& Chen, 2013; Thobani, 2000). In 1967, at the Convention and Protocol Relating to the Status of Refugees, a significant treaty in international law was developed and Canada signed on to this treaty in 1969 (Citizenship and Immigration Canada, 2006). Signing this treaty signified a move towards "non-discrimination in immigration policy; and cooperation between all levels of government and voluntary sector in the settlement of immigrants in Canadian society" (Citizenship and Immigration Canada, 2006). As such, Canada views the arrival of immigrants as an answer to sustaining the country's demographic and economic growth (Pullen-Sansfacon et al., 2013). Building on this, Canada's Ethnocultural Mosaic, 2006 Census defines newcomers or recent immigrants as "landed immigrants who came to Canada up to five years prior to a given census year," whereas the immigrant population is defined "as persons who are, or who have been, landed immigrants in Canada" but does not include non-permanent residents and individuals "born outside Canada who are Canadian citizens by birth" (Statistics Canada, 2010).

The Immigration Act of 1976 distinguishes among three categories of immigrants: economic immigrants, family-class immigrants, and refugees (Citizenship and Immigration Canada, 2006; Novak \& Chen, 2013; Thobani, 2000). Of the three categories, economic-class 
immigrants are known to be the largest group (about 67\%) of immigrants admitted to Canada (Novak \& Chen, 2013). Statistics Canada (2012) illustrated that 9 out of 10 Filipino immigrants fall under the economic class while the remaining $10 \%$ fall under the family class. Professionals from different countries are attracted by the economic opportunities available in Canada and come to Canada hoping their credentials and experiences will enable them to find work in their chosen professions (Bidhendi, 2006; Davidson, 2007; Novak \& Chen, 2013). Upon arrival, however, many racialized immigrants find that credentials which got them admitted to Canada as desirable citizens, are not recognized or valued by Canadian employers. Thus, their credentials and experience that once created a pathway to immigrate to Canada have now become a major barrier to obtaining a job or entering the labour market (Davidson, 2007; Fang, 2012).

The point system, which awards points to the credentials of skilled workers, was embedded in the Immigration Act of 1976-1977 (Citizen and Immigration Canada, 2006; Thobani, 2000). This immigration policy combined with the attractive economic conditions in Canada compelled skilled workers from many countries to immigrate to this country. (Lusis \& Bauder, \& CERIS, 2008; Türegün, 2011). The point system seeks to admit only highly qualified professional applicants (Fang, 2012). Most importantly, the launch of the point system opened the opportunity for Filipino healthcare professionals to immigrate to Canada (Kelly, 2006). Points are awarded based on education, age, language ability and previous employment experience, and yet the success of an application does not in any way guarantee the possibility of acquiring that same profession (George \& Chaze, 2012). This works to create immense systemic barriers and oppressions for Filipino-trained social work professionals who were able to gain access to Canada as professionals, yet who are unable to find work in their chosen profession. 
Citizenship and Immigration Canada amended the federal skilled workers' immigration policy in January 2015, calling the reform 'Express Entry'. The main goal of this program was to enable a more efficient and responsive immigration system (Citizenship and Immigration Canada, 2015). Applicants under this category are assessed through a points system which evaluates their 'suitability' for immigration. A minimum score of 67 out of 100 is required in order to qualify. This score is based on six factors: demonstrated competency in one or both official languages (English and French), educational attainment, employment experience, age, job offer, and adaptability (Citizenship and Immigration Canada, 2015). According to the Census Snapshot - Immigration in Canada: A Portrait of the Foreign-born Population, 2006 Census, during the period of 2001 to 2006, more than 1.1 million immigrants arrived in Canada. Of this large number of migrants, $58.3 \%$ were Asian-born immigrants and $7 \%$ were from the Philippines. (Statistics Canada, 2008). Since this time period, there has been an increase in the number of Filipino immigrants arriving in Canada and in 2010-2011, the Philippines became the top host country of landed immigrants in Canada (Statistics Canada, 2013). For example, according to Citizenship and Immigration Canada (2015), in 2005, there were around 18000 permanent residents from the Philippines and in 2014, that umber had jumped to over 40000. Upon immigrating to Canada, the majority of Filipino immigrants settle in Ontario and British Columbia. About $49 \%$ of Filipino immigrants live in Ontario while $21 \%$ live in British Columbia, 12\% live in Alberta, 9\% in Manitoba and 6\% in Quebec (Citizenship and Immigration Canada, 2015). Looking at the patterns of employment across several provinces, "[t]he majority of the Filipinos (83\%) were employed in one of three provinces: Ontario, British Columbia or Alberta" (Labour Program, 2013). "Almost half (49\%) of the Filipino workforce was located in Ontario, while another 22\% worked in British Columbia and 13\% worked in Alberta" (Labour 
Program, 2013). Focusing on the metropolitan areas, more than $40 \%$ of Filipinos are employed in Toronto and about 20\% in Vancouver (Labour Program, 2013). Based on these statistics, it is evident from the 1980s until present that more and more Filipino immigrants, particularly skilled and professional class immigrants, are choosing to make Canada their home every year. It is important for the economic and social well-being of these immigrants and their families, for professional immigrants to secure a job in fields such as social work. This study will seek to highlight the importance of government programs, immigration and settlement agencies, and social work agencies to create interventions which seek to address the ongoing social problems encountered by Filipino social workers and other racialized professionals. This could possibly lead to decreasing unemployment rates of Filipino-trained professionals in Canada.

Based on the 2006 Employment Equity Report: A Profile of Filipinos in Canada, Filipino immigrants obtaining university degrees are quickly on the rise (Labour Program, 2013). For instance, from 2001 to 2006, 46\% of Filipino immigrants have obtained a bachelor's degree or post-graduate degree. Within the last 10 years, "the number of university certificate or degree holders [in the Philippines] grew by 106\%" (Labour Program, 2013). Despite this increase in higher credential attainment, many Filipinos acquired these degrees outside of Canada. Interestingly, 33.4\% of Filipino immigrants have a university degree or certificate compared to $16.4 \%$ of the White dominant group in Canada (Labour Program, 2013). In spite of this vast difference in credential attainment, the dominant white mass continues to benefit systemically over Filipino-trained professionals.

The credential assessment of internationally-trained professionals is crucial to securing relevant employment in Ontario and in Canada overall (Davidson, 2007; Novak \& Chen, 2013). Within social work, one of the requirements to register with the Ontario College of Social 
Workers and Social Service Workers (OCSWSSW) is to have a foreign-obtained education that is equivalent to a minimum of a Canadian Bachelor of Social Work degree (Canadian Association of Social Workers, n.d.). It is the Canadian Association of Social Workers (CASW) that is in charge of the educational assessment of internationally-educated social workers (OCSWSSW, 2015). The organization oversees employment conditions for these workers and creates a standard of practice in the field (CASW, n.d.). The Canadian Association of Social Workers (n.d.) states that social work belongs to a group of regulated professions in Canada, and in order to practice the profession, a foreign-trained professional is required to submit an application to evaluate their social work credentials prior to applying for registration with the regulatory body in the province of Ontario. Citizenship and Immigration Canada (2013) suggests that foreign-educated professionals have to apply for credential assessment prior to moving to Canada as the evaluation process takes a maximum of three months to release the results. Such a suggestion by this government body may assist to minimize the delay in securing employment but further on in this paper, the researcher will demonstrate how systemic and structural barriers account for the unemployment and underemployment of foreign-trained Filipino social workers.

Pullen-Sansfaçon et al. argued in their (2013) work, that recognition of foreign-obtained credentials is the keystone to securing a social work job in Canada. Therefore, credential recognition influences the personal and professional adaptation of immigrants and has a significant impact on the identity formation of individuals and groups, especially racialized individuals (Galabuzi \& Teelucksingh, 2005). Their adaptation and ability to adjust are critical aspects of migration. Professional characteristics such as perseverance, flexibility and proactivity are indispensable to coping and adjusting to a new country (Pullen-Sansfaçon et al., 2012). Immigrants' ability to adjust in a new social environment, adapt to a new culture, and 
seek employment defines their position in society which shapes their advancement in a new country (Pullen-Sansfaçon et al., 2012). What this all comes down to, is that foreign-trained, racialized social workers, are systemically discriminated against in the hiring process.

Despite the difficulties in obtaining recognition for internationally-educated social workers' credentials, immigrants (including Filipino social workers) still assume that the standardized system of credential assessment and obtaining equivalency of international credentials to a Canadian bachelor's degree would provide them a better chance in finding relevant employment in Canada (George \& Chaze, 2012; Pullen-Sansfaçon et al., 2013). This assumption is in direct contrast to the federal government's claim that they cannot guarantee the employability of immigrants despite equivalency of foreign-obtained credentials (Citizenship and Immigration Canada, 2015). Moreover, the non-recognition or underutilization of foreigneducated professionals' credentials and experience greatly affects immigrants and their families from the Philippines and other countries who have invested in the profession prior to migration to Canada (Bloom \& Grant, 2001; Reitz, 2001; Watt \& Bloom, 2001). It prevents immigrant professionals such as Filipino social workers from practising their profession and forces them to settle for underpaid or menial jobs. This delays the re-establishment process for these professional immigrants and their families in the receiving country and ultimately creates a trickle-down system of oppression (Bloom \& Grant, 2001; Pullen-Sansfaçon et al., 2012). Building on this, the recruitment system utilized by Canadian employers - including social work agencies - which requires Canadian work experience to qualify for a job, deprives internationally-trained professionals such as Filipino social workers of the ability to practise their profession (Davidson, 2007; Novak \& Chen, 2013). In the Ontario labour market, 'Canadian work experience' is the gauge for identification of immigrants' capabilities and their capacity to 
perform a specific job, particularly social work, which is based on Canadian practices (Novak \& Chen, 2013). The 'Canadian experience requirement' limits the employability of internationally trained professionals from the Philippines and other countries and excludes them from Canadian labour market (Davidson, 2007; Grant, 2005; Novak \& Chen, 2013). Thus, employers fail to value the benefits of hiring internationally experienced professionals such as Filipino social workers due to the dominant discourses around foreign-trained professionals (Hall \& Sadouzi, 2010). Canadian employers' preference for employing professionals with Canadian experience plays a significant role in demoralizing immigrant workers without considering their competent professional backgrounds, ultimately negating the fact that foreign-trained social workers bring unique skill sets to their clients and colleagues (Davidson, 2007; Pullen-Sansfaçon et al, 2013). Man (2004) and Thompson (2000) suggest that when employers require Canadian experience, it increases the chances of disregarding immigrants' credentials, which can lead to higher rates of unemployment or underemployment, especially among racialized immigrants. A number of foreign-educated professionals get stuck in low-paying jobs due to the non-utilization of their foreign human capital (Alboim et al., 2005; Gray, 2005; Hall \& Sadouzi, 2010). These findings were also confirmed by the 2006 Employment Equity Report: A Profile of Filipinos in Canada. According to the report "more Filipinos were university educated than non-visible minority members, but they were still much less likely to hold managerial positions, or to be employed in professional and skilled occupations" (Labour Program, 2013). In the Canadian 2006 Canadian labour market, trends demonstrated that $4 \%$ of Filipino skilled workers were employed in management positions, $13 \%$ in professional positions, and $21 \%$ in skilled occupations whereas non-racialized workers were represented by $10 \%, 16 \%$, and $31 \%$, respectively. Furthermore, $44 \%$ of Filipinos were employed in semi-skilled occupations and 
$18 \%$ were employed in low-skilled occupations while non-racialized workers were represented in the same occupations at $31 \%$ and $13 \%$, respectively (Labour Program, 2013). The report also illustrates that Filipinos were more likely to be employed than members of the dominant group as only $5 \%$ of Filipino workers were unemployed than $6.2 \%$ of the dominant group. More specifically, Filipinos with university degrees experience higher unemployment (4.3\%) than the dominant group with the same level of educational attainment (3.7\%). Overall, these stark statistics demonstrate that in spite of the fact that White populations are overrepresented in the unemployment sector and a higher percentage of Filipino workers are professionally educated, the dominant discourses around foreign-trained professionals render them systemically marginalized and oppressed in the search to secure employment.

The above statistics further demonstrate that Filipino professionals and skilled workers are marginalized in organizations, companies and the overall Canadian labour market and are most likely represented in the statistics for semi-skilled and/or low-skilled occupations. Overall, although Filipinos have a lower unemployment rate than Whites and other racialized minorities, skilled Filipinos with university degrees experience higher unemployment compared to Whites (Labour Program, 2013). This could possibly be attributed to the notion that social service employers, have a tendency to hire employees that have Canadian experience and credentials, and reflect the same White norms and cultural standards as their agency or organization.

In 2007, the federal government established the Canadian Immigrant Integration Program to reach out to and assist foreign trained professionals in their hunt to secure employment (Novak \& Chen, 2013). This online program aims to assist newcomers to successfully integrate into the labour force by providing employment-specific and settlement information prior to migration. Despite the federal government's efforts to assist immigrants prior to migration, this 
government program, along with immigration settlement agencies such as Skills for Change and Jump Start, fail to provide accurate pre-migration information on the real-life situation of immigrants in Canada, or post-migration services upon immigrants' arrival to the Canada (Lusis \& Bauder, 2008). Lusis \& Bauder (2008) go on to state that accurate information dissemination prior to leaving their home country would benefit immigrants and could help them to prepare for a new system. culture and environment. By informing them in advance, immigrants will not be surprised by the vast obstacles they may encounter upon arrival to Canada and thus may be better equipped to navigate such barriers. (Lusis \& Bauder, 2008; Novak \& Chen, 2013).

\section{Language Barriers to Employment:}

Barriers such as language competency and accent were also revealed as challenges to internationally educated Filipino social workers successfully re-launching their social work career in Canada (Cheng et al, 2013; Davidson, 2007; Ngo \& David, 2006; Sinacore, Mikhail, Kassan, \& Lerner, 2009). Literature demonstrates that language becomes one of the major impediments to secure a suitable job for foreign professionals for whom English is not their first language (Sinacore, Mikhail, Kassan, \& Lerner, 2009). Foreign-trained Filipino social workers' inability to communicate in English or French can be a major barrier to obtaining a job in Canada, even when seeking work within their own communities (Novak \& Chen, 2013).

A high level of English and/or French competency is one of the requirements to immigrate to Canada. A candidate must achieve at least a "7" on the Canadian Language Benchmark for the first of four (4) language proficiency tests categories such as listening, writing, reading and speaking (Citizenship and Immigration Canada, 2015). In order to gain points for another language, a candidate must earn a Canadian Language Benchmark score of qt least five points on all four language proficiency categories (Citizenship and Immigration 
Canada, 2015). Low competency levels in one of the two major languages in the country may lessen foreign educated professionals' chances of obtaining employment, for communication skills are vital in the workplace, including social service agencies (Chiswick \& Miller, 2003; Conference Board of Canada, 2004; Novak \& Chen, 2013). Learning English and/or French demands the investment of time and money which many immigrants struggle to attain in spite of their already advanced education (Sinacore et al., 2009).

Davidson (2007) expounds upon the idea that mainstream employers identify applicants through their "accent", which is a clear form of racism in the job market. Given that in Canada, a professional's native accent is often a mainstream employers' basis for measuring employment competence, anti-racism scholarship must break down this power imbalance. For the reasons stated above, racialized employment applicants are less likely hired by Canadian employers due to their non-native English accent which is often constructed as undesirable and incompetent, regardless of professional credentials (Gou, 2009). Anti-racist scholarship calls this out as one of the most central processes of racialization practiced by employers in Canada, which works as a significant barrier to employment.

\section{Economic Barriers to Employment:}

Financial hurdles play a large role in securing professional advancement, which creates frustration for foreign-educated professionals (Cheng, Spaling \& Song, 2013; Ngo \& Este, 2006). In order to secure a relevant, professional job, Filipino social workers pursue education upgrading and training at their own expense (Hall \& Sadouzi, 2010).

Foreign-trained Filipinos social work professionals immigrate to Canada to seek economic progress for their families (Lusis \& Bauder, 2008). Immigration application costs an average paid Filipino professional a few months of remuneration, and in most cases, their 
applications are financed by relatives who are working abroad, or the applicant's earnings from previous work overseas (Kelly, 2006). In most cases, money brought to support their families while re-establishing a career in their host country is used from their pool of savings, sold properties and loans. Hence, further education and training on top of daily expenses exhaust their overall household budgets creating financial oppression and acting as an additional hurdle to securing employment (Hall \& Sadouzi, 2010). As a result of these factors, many postpone successful integration into the labour market (Novak \& Chen, 2013). Filipino immigrant social workers often take on many jobs to be able to support themselves and their families financially. Typically, these employment opportunities are constrained to less secure, labour-intensive jobs which are unrelated to their profession and which exploits these foreign-trained professionals. (Novak \& Chen, 2013; Lusis \& Bauder, 2008; Samuel, 2009; Teo, 2007; Türegün, 2011).

The above literature review included the Facts and figures 2014 - Immigration overview: Permanent residents (Labour Program, 2013); Immigration Database 2008 Immigration Category Profiles (Citizenship and Immigration Canada, 2015); 2006 Employment Equity Report: A Profile of Filipinos in Canada (Labour Program, 2013); Distribution of Filipinos by educational attainment and occupational skill level (Labour Program, 2013); systemic barriers (Alboim, Finnie \& Meng, 2005; Davidson, 2007; Lusis \& Bauder, 2008; Novak \& Chen, 2013), language barriers (Davidson, 2005; Cheng et al., 2013; Ngo \& Este, 2006; Sinacore, Mikhail, Kassan, \& Lerner, 2009), and economic barriers (Cheng, Spaling \& Song, 2013; Ngo \& Este, 2006) experienced by the internationally educated Filipino social workers in Canada. Ultimately, this empirical data worked to strengthen the upcoming study conducted based on the lived experience of Filipino-trained social work professionals. 


\section{CHAPTER 4. RESEARCH DESIGN}

\section{Purpose of the research}

Filipino social work professionals are among the skilled immigrant population who have come to Canada expecting to be able to practise their chosen profession. As stated above, given the high influx of Filipino skilled immigrants compared to other racialized groups in Canada, specifically within the province of Ontario, this research will seek to outline the significance of providing accurate information to these individuals about the employment and economic realities and related social obstacles they will encounter upon arrival to Canada. The barriers encountered by internationally-educated Filipino social work professionals in Canada during their attempt to integrate into the labour force will be viewed through an anti-racist lens which problematizes these oppressive practices in the industry, which must be unveiled in order to be addressed.

The purpose of this qualitative, phenomenological research is to gain an understanding of the challenges encountered by internationally-educated Filipino social work professionals when they attempt to secure a social work career in Canada, and examines their realities from their own perspectives. This study intends to privilege the voices of internationally-educated Filipino social work professionals who have been silenced and provide awareness of their realities to policy makers, politicians, immigration settlement agencies, social work programs in postsecondary institutions, and other Filipinos considering to make Canada their future home.

According to Potts and Brown (2005) "committing ourselves to anti-oppressive work means committing to social change and to taking an active role in that change" (p.255). This research desires to contribute to two anti-oppressive changes for internationally-trained Filipino social workers. Firstly, it will seek to implement new anti-oppressive hiring practices in social work agencies for this population specifically as well as, more broadly, all racialized minorities. 
Secondly, this research aims to influence social work agencies to recognize the equivalency of foreign-obtained credentials of Filipino social workers approved by the Canadian Association of Social Workers in order to give them equal opportunity to compete in the hiring process.

\section{Research Questions}

This study explored the lived experiences of internationally educated Filipino social workers and identified the challenges they encounter while they attempt to secure a social work career in Canada. To seek understanding of the participants' social realities, open-ended questions were employed, allowing participants to share their lived experiences, and examine how they develop meaning out of them. The research sought to answer three questions:

1. What are the lived experiences of internationally-educated Filipino social work professionals as they attempt to secure social work employment in Ontario?

2. What are the challenges or barriers encountered by internationally-educated Filipino social workers during the hiring process?

3. What role does systemic racism play in the lived of experiences of internationallyeducated Filipino social workers in Ontario?

\section{Methodology}

Qualitative research is appropriate when a phenomenon is unclear and demands exploration of the topic to provide a richer understanding of the target population's social realities (Creswell, 2005; Neuman, 2003). This research design is usually employed when little to nothing is known about a certain phenomenon, or when the researcher desires to obtain an in-depth understanding of human experience (Faulkner \& Faulkner, 2014). One particular type of qualitative research which is conducive to this study is phenomenology. 
Thus, this research explored the lived experiences of internationally-educated Filipino social work professionals and identified the barriers they encountered while they attempted to integrate into the Canadian labour force. While conducting the research and investigation phase of this study, as an insider, I had to examine my own personal judgements and experiences applying for and/or interviewing for social work jobs in Ontario, Saskatchewan, and British Columbia. In phenomenological research, this process is known as epoche. According to Moustakas, as cited in Mariam and Tisdell (2015), epoche is "a Greek word meaning to refrain from judgement and in the Epoche, the everyday understandings, judgements, and knowings are set aside and the phenomena are revisited" (p.27).

The concept of phenomenology was first developed by the German philosopher Edmund Gustav Albrecht Husserl (Groenewald, 2004; Moustakas, 1994a). Hursserl "rejected the belief that objects in the external world exist independently." (Groenewald, 2004, p. 4). He believed that experience is a source of knowledge, and asserted the certainty of personal consciousness. Hursserl also stated that "Realities are thus treated as pure 'phenomena' and the only absolute data from where to begin.” (Groenewald, 2004, p. 4). The phenomena of interest in this study is the lived realities of Filipino social workers. In this phenomenological study, the aim of this research is arrive at certainty. To do this, the personal consciousness of the Filipino social workers are reduced to external reality. As such, phenomenology was utilized to create knowledge about the experiences of Filipino social work professionals during their attempt to integrate into the Canadian labour force and to highlight the lived realities of this population. 
According to Creswell (2012), the phenomenological approach focuses on illustrating the commonalities of the participants as they face a specific phenomenon.

Cresswell goes on to state that the illustration consists of "what" they have encountered, and "how" they have encountered the phenomenon (2012). It is used to explore the social realities of this community and to gain a deeper understanding of a phenomenon, based on the opinion of people who experience it (Shank, 2006). Flood (2010) argued that individuals' social realities are mainly influenced by their environment. She further stated that phenomenological research aims to describe individual experiences, and to understand the "cognitive perspective" of the subject and how it effects his or her life (Flood, 2010, p.10) In this study, the realities of Filipino social workers are impacted by ongoing structural and systemic issues in the Canadian labour market. Phenomenological research provides me with the opportunity to gather data based on the participants' own perception and understanding of their experiences within the Canadian context.

\section{Participants}

Creswell (2007) states that even a small sample can represent a reasonable population size, as quality is crucial in qualitative research, not quantity. Therefore, a sample of four internationally-educated Filipino social work professionals were selected for the purpose of this study. They were recruited through online advertisements on both Charity Village and Kijiji. Initially, after 1.5 weeks of posting one advertisement on each site, I received a notification to re-post the advertisement but still no interested participants. I re-posted the advertisements and after an additional 1.5 weeks, I received two responses from interested participants who had heard of the study via Charity Village. To address this 
limitation, I introduced snowball sampling in my recruitment process, where volunteer participants were asked to recruit other participants for the study.

Snowball sampling is a non-purposive sampling technique that is used based on the researcher's study interest and discernment (Biernacki \& Waldorf, 1981). This type of sampling is used to recruit difficult-to-access populations such as the one in this study. It involves participants in the recruiting process by having them recruit other potential participants in order to complete the sample size (Atkinson \& Flint, 2001). The advantages of snowball sampling includes the fact that it can be inexpensive, efficient, and saves the researcher time in locating participants (Atkinson and Flint, 2001). Further, it allows the researcher to access populations they might otherwise not be able to gain access to.

The two participants from Charity Village recruited one participant apiece. I, as the researcher, ensured that participants' involvement in the study was completely voluntary by providing a thorough explanation of their rights as participants including their right to refuse in the event they decided not to be solicited as a possible source of referral for study participants. This action aimed to address possible feelings of obligation or coercion felt by these initial two participants in recruiting other potential participants for the study.

The following criteria were used to recruit the samples on Kijiji and Craiglist: being a Filipino social work professional, having obtained education and professional experience in the had to be registered with the Ontario College of Social Workers and Social Service Workers.

This study was limited to the experiences of four participants and therefore, it is not representative of the entire internationally-educated Filipino social work population in Ontario. The first participant was a female social worker who immigrated to Canada through spousal sponsorship as her husband was Canadian. She has been in Canada for 6 years and is considered 
a family class immigrant. The second participant was a male social worker who immigrated 5 years ago as an economic immigrant. The third and fourth participant are both females who have been in Canada for 9 years and are both economic class immigrants.

\section{Data collection methods}

For this study, semi-structured interviews were utilized along with audio recording and note-taking. In phenomenological studies, interviews are the central data collection method which aims to uncover the essence or invariant structure (Moustakas, as cited in Mariam \& Tisdell, 2015). By 'essence' or invariant structure', Moustakas refers to the 'basic underlying structure of the meaning of an experience" (Mariam \& Tisdell, 2015, p.27). It is this essence of the experience which I, as the researcher, sought. Interviews were conducted face-to-face for a duration of 45 to 60 minutes each and the interview was audio-recorded. Audio recording is a process where the researcher asks questions, observes non-verbal cues, and engages some in note-taking (Padgett, 2008). It gives the researcher the convenience of not having to take notes verbatim but rather the ability to focus on listening and understanding all of the information provided by participants in the moment (Creswell, 2012). It also assists in building rapport with the participant and allows for the interview process to remain uninterrupted and more organic (Smith and Osborn, 2007).

In relation to my study, audio-recording gave me the opportunity to concentrate on the participants' responses during the interview process. Subsequently, during the process of transcribing the interview data, audio recording captured in detail how participants described their experiences and how they attached meaning to those experiences. In addition, as one transcribes each interview, "one needs to see all words spoken including false starts; significant pauses, laughs, and other features" (Smith and Osborn, 2007). Transcribing audio-recorded 
interviews takes time, and is contingent upon the quality of the recording and the researchers' typing skill, but is highly effective (Smith and Osborn, 2007). In this study, it took me approximately 6 to 8 hours to transcribe each interview as I reviewed the interview data repetitively to ensure I heard and typed each word accurately. Audio recording can also be limited as it does not capture non-verbal cues, body language, and other nuances. Thus, it important to utilize field notes as well (Smith and Osborn, 2007).

According to Groenewald (2004), humans have a tendency to forget easily, thus to prevent this, it is important to record field notes and observations during the interview process using all the senses. When recording, Groenewald (2007) suggests researchers should be disciplined and non-judgemental. In this study, I recorded non-verbal observations and carefully avoided personal judgements so as to exist in the moment with the participant in order to truly hear what they were telling me.

All four semi-structured interviews took place at the Ryerson University Library at 350 Victoria Street Toronto, Ontario. Smith and Osborn (2007) consider semi-structured interviews as "flexible data collection instrument" which is a useful method to examine in detail how participants perceive and understand their experiences (p.57). The authors state that this type of interviewing involves an ongoing dialogue between the researcher and the participant. They also state that it provides the researcher a chance to modify the questions in accordance to the participants' interests and concerns based on their responses, and probe interesting ideas that may be revealed. In this study, the researcher formulated an interview guide which consisted of 9 items. She also asked follow-up questions to the 4 interviewees. On May 4, 2015, the researcher interviewed the first participant. The second participant was interviewed on May 11, 2015 and the third participant was interviewed on May 19, 2005. The fourth participant was interviewed 
on May 22, 2015. All four participants both resided and worked in the same vicinity as the university.

\section{Data analysis methods}

For the transcription and data analysis process, I used the steps outlined by Hycner (1985) related to phenomenological research. While engaging in the transcription process, I employed the use of bracketing which is "suspending...as much as possible the researcher's meanings and interpretations and entering into the world of the unique individual who was interviewed" (Hycner, 1985, p.281). I examined my point of view and experience about the topic being studied and intended to bracket it to produce an accurate description of the participants' experiences. Furthermore, I remained open to the meanings and themes from each participant which emerged during this process (Hycner, 1985).

Creswell (2012) elaborates on the steps of phenomenological data analysis by Moustakas (1994b), and states that phenomenological data analysis is based on the interview transcriptions that were reviewed by the researcher and "highlights significant statements, sentences, or quotes that provide an understanding of how the participants experienced the phenomenon" (p.82). To begin the transcription process, I actively listened to each audio-recorded interviews several times, and listed every significant statement, along with non-verbal language, related to participants' experiences. The audio-recorded interviews enabled me to go back, and carefully listen to every interview to produce verbatim transcriptions, while I familiarized myself with each response.

After transcribing, I went through every statement and created a textural description. According to Padgett (2008) "[t] extural description is the synopses of every participant's experiences" (p. 150). Following this, I noted in detail every significant word, phrase, sentence 
and non-verbal cue observed during the interview, and completed structural descriptions on them. Structural description is the "examination of the context and setting of these experiences and summary of major themes from the information collected" (Padgett 2008, p.150). As I went through the transcript, I was able to highlight the commonalities and differences in the participants' responses. Every response was examined based on relevance and sufficiency for understanding the experience, and whether it could be outlined and labelled. Other responses that were not relevant for inclusion were eliminated.

Following this, I developed titles out of all of accumulated meanings of the above statements and listed all "non-repetitive and non-overlapping statements" (Creswell, 2012 p.5). I then grouped these titles according to their conceptual similarities and meanings to connect overarching themes. This step is called "clustering and thematizing the invariant constituents" (Creswell, 2012; Moustakas, 1994, p.4). Lastly, clustered themes were reviewed to produce core themes.

\section{Ethical considerations}

Approval to conduct this research was granted by the Research Ethics Board of Ryerson University as the study involved human subjects (See Appendix). Participants were informed of confidentiality and privacy policies, including the right to withdraw from the study at any time. To ensure confidentiality, pseudonyms were used on all study materials including audiorecordings, transcripts and other documents related to the participants. All audio-recorded interviews were stored in a password-protected recorder, and were transferred to a passwordprotected computer, while transcripts and other documents related to the participants were locked away safely. These measures were undertaken to ensure the privacy of participants and to fulfill the ethical obligations of research. 


\section{CHAPTER 5. FINDINGS}

This chapter presents the findings of the study reported in this Major Research Paper. The four semi-structured interviews utilized for this research were analyzed using phenomenological data analysis. After summarizing the experiences of the four participants, I categorized them into eight over-arching themes, and then through further analysis, I recategorized them into the following four major themes: (1) Systemic barriers to employment; (2) nepotism and a lack of connections; (3) personal barriers to employment and (4) a lack of knowledge regarding Canadian legislation and the social welfare system. The first sub-section of my findings (systemic barriers to employment) was the most significant component of my findings and thus will be broken down into two sub-sections as follows: (1) the devaluation of foreign-obtained social work experience and (2) insufficient/inaccurate pre-departure seminars, information and support services. These four over-arching themes and two sub-themes were selected via a phenomenological analysis of the data presented by all four participants and together, make up the findings of this research.

\section{Systemic Barriers to Employment}

The first major theme which was identified by participants was the effect of systemic barriers on them finding employment in Canada. In addition to the systemic barriers related to immigration which are evident in the host country, all four participants, upon arrival to Canada, experienced systemic barriers related to racism in the labour market. These include the devaluation of foreign-obtained social work experience, insufficient and inaccurate pre-departure seminars, insufficient support services and personal barriers to employment which were systemically reinforced. 
Through an analysis of participants' responses, it became apparent that each one of them had experienced systemic oppression in the form of racism and report that these barriers impacted their socio-emotional, financial, and psychological well-being. White privilege and norms were evident in the challenges the four participants encountered when they attempt to gain employment in the social work field.

\section{The De-Valuation of Foreign-Obtained Social work Experience}

All of the participants in this study shared that they sent out many resumes but only two participants got interviews. These two participants, Theresa and Jude, verbalized their feelings of degradation after being asked by the interviewer if they possess "Canadian experience." They reported feeling discriminated against for not having Canadian social work experience. The majority of them stated that they expected to practice social work as soon as they arrived in Canada, particularly given the advertisements all had been subject to which spoke of the high need for skilled workers in Canada. In reality, all of the participants revealed that they started working menial jobs instead.

Theresa: I sent 100 resumes in a month, I did it full-time on a daily basis from nine o'clock in the morning up to five in the afternoon, and I also tracked the resumes I sent. After two months I had my first social work job interview. The panel said, "Okay before we proceed do you have a paid Canadian social work experience?" I tried to sell myself to the point I got so frustrated because they were really emphasizing that I do not have a paid Canadian social work experience. So right then I knew I would not get the job. Later on I ended up working in a retail store.

Jude: I did not expect that I had to experience the cold shoulder that employers will ask you for Canadian experience and where are you from. How will I know Canadian social work practice if they will not give me a chance to abreast myself in Canadian context. I really started from scratch so when I came here I really had a difficult time. I started in survival work; I was a maintenance staff in a senior's housing. I had to do all the cleaning and all that stuff, and was paid with a minimum wage which is not even enough to pay an apartment. 
Theresa's experience interviewing for a social work position is quite telling - rather than crediting or acknowledging her volunteer experience in the Canadian social service sector, or her professional social work experience in the Philippines, the employer specifically asked her for "Canadian paid social work experience."

In his interview, Jude stated that he felt discriminated against because he was considered a newcomer compared to Canadian-educated social work professionals. According to antiracism theory, the "Canadian experience" requirement in mainstream social work agencies' hiring systems delegitimizes the foreign-obtained professional experience of these two individuals as well as other skilled immigrant workers (Alboim, Finnie \& Meng, 2005; Davidson, 2007; Yee et al., 2007). In addition, mainstream social work agencies appear to measure an applicant's competency based solely on Canadian experience. Within these agencies, the definition of 'Canadian experience' is "Canadian social work practice" and "paid Canadian social work experience". Underlying the discourse of 'Canadian experience' is a form of racial oppression, which gives more privilege to applicants associated with White norms and values in Canadian social work agencies' hiring practices. The length of time these four participants have lived in Canada ranges from 5 to 10 years. All four of these foreign-trained, Filipino social workers are still undergoing the assimilation process and some are still considered newcomers by the definition outlined above from the Census conducted in 2010 by Statistics Canada. Thus, according to Canadian discourse, they do not possess the White values and norms required to obtain employment in Canadian social work agencies. The 'othering' of these participants along with other racialized groups in Canada - can be viewed as a prevailing practice of systemic racism in Canadian hiring practices. 
To address the systemic oppression experienced by foreign-educated social workers, Ryerson University established the bridging program (Davidson, 2007). Davidson (2007) asserts that the Internationally Educated Social Work Professionals Bridging Program has been effective in addressing the barriers encountered by internationally educated social workers. He outlined the components of the bridging program, which include an English language course, and provision of knowledge about Canadian social work practice. As demonstrated in her interview, Martha had the courage to deconstruct the mainstream concept of "Canadian experience" by attending Ryerson University's bridging program for internationally educated social workers in order to seek employment. She shared that despite completing the program, she still experienced significant difficulty fitting into the social work stream that she wanted to pursue, given that employers continued to ask her about her Canadian experience in that particular setting:

Martha: In the Philippines, I was a generalized social worker, I did not have a specialization. Even though I know in myself that I can do specialized social work practice, I am having difficulty convincing the agencies to give me a chance because I don't have Canadian experience in that setting.

Martha's experience speaks to the systemic racism and barriers that Filipino social workers face in the Canadian job market.

The perseverance of foreign-trained Filipino social workers is evident in their continuous effort to acquire employment in the social work field. Two of the participants, Ella and Martha, felt discriminated against after not getting any social work job interviews despite sending out numerous resumes to prospective employers.

Ella: I felt discriminated because even I had my education assessed as equivalent to Canadian bachelor's degree, registered with Ontario College of Social Workers and Social Service Workers and sent out too many resumes I never received any telephone call or any confirmation of my applications, as in no response at all. I ended up working in McDonalds and a factory job. 
Martha: I searched for a social work job on my first six months here in Canada but did not get any interviews. The show money I brought was already running out so I made a decision to work as a part-time cashier in a small convenience store in order to survive. It is painful to be discriminated. Even with the cashier job I was not able to get full-time hours too. My shift was just five to six hours in a week which is not enough to support my monthly expenses.

It is clear that all the participants, including Martha, interacted with social work agencies who embraced White norms as standards of practice, as they were all told repeatedly that they 'lack Canadian experience'. The constant iteration of the phrase 'Canadian experience' caused participants to express that they felt their experience and education were devalued solely based on discriminatory racial practices.

Theresa and Jude were quite disappointed as they thought their specialization as a clinical social worker and psychotherapist, respectively, would have given them a higher chance of obtaining recognition in Canada for their experiences in the Philippines:

Theresa: I was a clinical social worker back home. So, I was under the impression that when I come to Canada my experience will be an advantage. I was wrong. The employers devalued my experience. As in they did not pay attention, they did not consider it.

Jude: I had an extensive experience as psychotherapist from my home country but my experience was devalued. Employers still looked for Canadian experience.

The devaluation of foreign-obtained social work experience has been an on-going issue of systemic oppression experienced by foreign-trained professionals (such as these four Filipino social workers) and racialized skilled workers in the labour market (Yee et al., 2007). These professionals have been treated as 'less than' which ultimately degrades them and deprives them o the experience of pursuing a social work career in Canada (Davidson, 2007; Novak \& Chen, 2013; Pon, 2004). The reality about Canadian hiring practices is that they can be seen as directly responsible for the underemployment and unemployment of foreign-trained professionals, particularly social workers (Man, 2004; Thompson, 2000). 
Given this re-occurring social exclusion and oppression of foreign-trained social workers, all four participants in this study decided to volunteer with Canadian social work agencies in order to gain the required experience. Volunteering ultimately had an impact on participants' employability and all of them identified that volunteer jobs helped them to acquire employment as social workers. In spite of the fact that it helped them to attain employment in the field, it is highly problematic that this is a requirement for foreign-trained social workers, and further, that there is not more transparency around this seeming requirement to gain employability in Canada as a foreign-trained social worker. All four participants in this study had differing views on their having to volunteer in the Canadian workplace to be seen as employable in Canada:

Theresa: I volunteered with the Out of the Cold Program and Feeding Program. It helped me a lot; I met several people who were also on the same shoes. They encouraged me and told me that I am not alone. Talking to them and listening to their stories helped me to accept that it will never be easy to get the job that you are passionate about.

Jude: Volunteer worked for me, I learned a lot of stuffs. I was able to assimilate to Canadian culture and understand what it means to work in a social work field here in Canada. They gave me the opportunity to attend some seminars that helped me grasp to Canadian social work practice. But you know at first I was hesitant to volunteer coz my priority was to support my family's needs. I was thinking at the back of my mind, volunteer would take up some of my hours without getting paid.

Ella: In my volunteer jobs I was able to mingle with employers and they gave me some suggestions on what to do and what to expect during job interviews. I did mock interviews with the employers. It really helped me a lot.

Martha: My settlement counsellor told me that I should get a volunteer job in order to set my foot in the door. I'm like.. I told myself, I need money to provide for myself. I will not be able to do that by volunteering. But still I tried to volunteer in their agency and worked with youth, after two months I was hired as a part-time youth worker.

In spite of the fact that all four participants recounted that these experiences assisted them in learning about Canadian workplace culture, the interview process, and networking as well as assisted them in finding employment, that they had to conform to Canadian workplace culture in 
the first place is highly problematic. When looked at through the lens of anti-oppression and antiracism, what participants were really speaking of was the necessity of assimilating to the culture of white, mainstream social work agencies and adopting White norms and values.

Jude and Martha both discussed feelings of disempowerment due to having to volunteer to get Canadian experience but not getting paid for their invested hours. As Jude spoke about, volunteer hours were a necessity for him in the context of assimilating into Canadian social work practice but, at the same time, every hour spent volunteering took away from his ability to provide for his family. Thus, the stipulation that social workers practicing in Canada have Canadian experience created a cycle of oppression which de-stabilized his entire family.

An interesting facet of these interviews is that neither Martha nor Jude spoke about these oppressions through the lens of racial oppression, possibly because they had accepted the structural inequalities in the system as status quo. Further, Theresa and Ella were silent about their feelings of disempowerment, possibly indicating that they have accepted the idea that practicing from a lens of dominant, White social work (and thus requiring Canadian work experience) is status quo in Canada. Theresa further indicated that she met other immigrants and adopted coping mechanisms in the form of support groups, listening to stories and taking encouragement from them. These other individuals who were experiencing the same challenges held a false consciousness as they felt that their unemployment status was due to the fact that they had to 'accept' that getting a job one was passionate about was not easy and thus they had to work harder. This discourse was apparent in the blatantly discriminatory hiring practices of Canadian social work agencies. In spite of this, neither Theresa nor individuals in the same position as her discussed racial oppression as a factor in their failing to acquire employment; rather, this research queries whether Filipino-trained social work professionals have seemingly 
accepted this racial oppression as status quo in the Canadian hiring market. Similar to Theresa, Ella was also silent about racial oppression and only focused on interacting with employers who could help her get a job (or in other words, she remained silent on systemic oppression and chalked her experiences up to individual failure rather than systemic failure.

Prior to coming to Canada, unlike Theresa who was sponsored by her husband and did not have to attend immigration interviews, Jude, Ella and Martha shared that they each had to attend an interview with the Canadian immigration office in the Philippines. During this interview, queries were related to job history and skills, which were identified by some of the participants as misleading. For example, the questions included: What is your profession? What are your work experiences related to social work? What are your job responsibilities? Questions such as these are blatant attempts by the system to weed out individuals who are foreign-trained and who lack domestic social work experience. When queried as to what they believed these questions were designed to measure, three of the four participants endorsed the belief that these questions were designed to measure the transferability of their skills and determine their knowledge about the profession. Upon breaking these questions down through an antioppressive, anti-racist lens it becomes evident that these questions are designed to measure an individual's co-optation to the dominant, White norms of Canadian social work practice.

Three of the participants in this study spoke to their belief prior to immigrating that given their ability to speak at length about their social work skills and expertise in pre-immigration interviews, they would have little difficulty finding jobs in Canada.

Jude: As I remember the focus of the interview at CIC (Citizenship and Immigration Canada) office back home was my job experiences and my education background. I assumed that I will be able to get a social work job here in Canada right away because I passed the interview, and I was offered to migrate. 
Ella: The consulate officer did not tell me the reasons beyond the questions in the interview, he asked me about my job and my responsibilities as a Social Worker. So, I was expecting that I can pursue social work easily when I get here.

Martha: In the interview with the Canadian Immigration officer in the Philippines, I was asked what are my skills? What are my qualifications as a social worker? I was also told by the officer that "yea we need social workers in Canada." So I expected that it would be an easy transition for me to get a social work profession in Canada.

Based on the interviews conducted, all three of these participants assumed that they had essentially passed the pre-employment requirements and would be able to find jobs in Canada. It seemed that these 3 participants 'assumed' or 'expected' that their responses to these questions would be indicative of their social work job and knowledge competency and would guarantee that they would secure social work employment in Canada once they immigrated. Additionally, these 3 participants seemed to believe that the Immigration interviewers from Citizenship and Immigration Canada also asked questions to measure their degree of employability. In reality, they were only measuring participants' eligibility to enter Canada as immigrants who were economically stable and not dependant upon Canadian social welfare systems.

As all three of the above mentioned participants learned upon arrival to Canada, these pre-placement interviews in no way assisted them in obtaining employment. The above statements are all demonstrative of the rampant systemic oppression that works against foreigntrained social workers seeking employment in Canada. Further, based on the lack of preplacement information, as will be explored in the next section, and the structure of pre-placement interviews and the job-related interview questions, immigrants were lead to believe that they would easily obtain employment and that they had already met the standards for Canadian social work practice. Ultimately, the devaluation of foreign social work experience, as was discussed 
above, and the inaccuracy of pre-placement interviews and support services, as will be discussed below, work to systemically marginalize and oppress foreign-trained social work professionals.

\section{Insufficient/Inaccurate Pre-Departure Seminars, Information and Support Services:}

One of the first findings that became evident in this study is that prior to immigrating to Canada, all four participants felt inundated with advertisements by employment agencies encouraging skilled Filipino workers to immigrate to Canada, Australia and other countries, promising work once they arrived. Participants endorsed seeing these advertisements both in the universities they attended in the Philippine's, and also in the mainstream media such as television and newspapers. Universities in the Philippines informed these four participants (and others) that if they chose to enrol in their social work program, they would easily obtain a job abroad. Further, all four participants reported that partially due to the volume of this advertising, they viewed Canada as a rich country and as being more progressive and developed than the Philippines. Ultimately, all four participants reported that they decided to come to Canada for a better life, as promised in the prolific advertisements encouraging them to come work abroad.

The volume and type of information available to each of these participants prior to immigration was dependant, in part, upon the pathway through which they sought entrance to Canada. Theresa immigrated to Canada through spousal sponsorship, Jude and Ella immigrated with their families and Martha immigrated independently. As a result of this, Theresa participated in the pre-departure orientation seminar at the Commission on Filipinos Oversees and Jude, Ella, and Martha attended the same seminar at both the Commission on Filipinos Oversees and the Canadian Embassy in the Philippines. None of the participants had family in Canada and thus, during their assimilation process and related job search, they relied exclusively on government support and agencies, immigration and settlement agencies, and employment 
agencies. All four participants reported that these services were woefully inaccurate and insufficient.

Each of the four participants in this research narrated their experience in pre-departure seminars held in the Philippines by the Canadian Embassy and the Commission on Filipinos Oversees, which they described as: general in nature, insufficient, and deceiving regarding employment opportunities. The lived realities of all four participants were in line with the work of Lusis and Bauder (2008) who reports that the Canadian government and immigration settlement agencies fail to provide fact-based pre-migration information on immigrants' real-life situations in Canada or, in other words, which fail to represent the lived experience of migrants. Ultimately, all four participants reported that false advertisements in universities, television, radio, newspapers, and employment agencies within Philippines allured them to migrate to Canada as professionals.

Theresa: The pre-departure seminar held by the Philippine government lasted for only thirty (30) minutes, it was not enough, and judgmental; I was criticized because of my marital situation. It was a fraud, they charged us five hundred (500) Pesos for providing us inaccurate and inadequate information. Talking about advertisements, Filipinos are encouraged to migrate to Canada in most print ads and T.V. commercials. To increase social work enrolees in the universities they would promote social work as one of the professions needed in Canada, UK, New Zealand and Australia. The companies or agencies are taking advantage of the worsening economic situation in the Philippines by releasing wrong advertisements about employment opportunities in Canada.

Jude: The advertisements back in the Philippines including the pre-departure information session about coming to Canada are all positive. It's like alluring you to really migrate to Canada. I was led to wrong expectation that I will be able to practice my profession, that jobs are flourishing, and I will not have a hard time looking for a social work job. That was the thing that was implanted in my mind. Honestly none of what they have said are true. The PDOS (Pre-Departure Orientation Seminar) by the Philippine government was insufficient. They talked about migration in general because the attendees were immigrants and overseas workers from different countries.

Ella: The pre-departure seminars conducted by the Philippine government and the Canadian Embassy were both inaccurate. The Canadian Embassy projected a positive 
image of Canada that there are a lot of job vacancies and settlement is going to be easy. The Philippine government's pre-departure seminar was actually brief. They promoted banks and some remittance services that we could use once we get here, actually nothing about Canada. All advertisements back home said that Canada needs workers.

Martha: Honestly, the information provided in the pre-departure seminar by Canadian immigration did not really matter to me at first because everything they have said was positive. So I had high expectations. When I started to look for a job, that's when I knew that it was false information. Everything back home about Canada was positive, even advertisements promote job vacancies in Canada, that Canada needs a lot of skilled workers. The PDOS (Pre-Departure Orientation Seminar) provided by the Philippine government was too general, not about Canada in specific. I can't believe how the advertisements in the Philippines promote Canada as one of the foreign countries that scarce human resources. In reality, yeah jobs are available, but not for immigrants.

As stated above by all 4 participants, the false nature of the information provided to them premigration regarding the alluring opportunities in Canada meant that they essentially migrated under false pretences. Further, as all four reported, they ultimately immigrated to a country in which their foreign-obtained credentials and job experience were not recognized due to the falsehoods inherent in government discourse surrounding immigration.

When analyzed from a phenomenological perspective, it became apparent that the false perception about immigrants' success in Canada is mainly rooted in misleading immigration interview queries, deceptive advertising and inaccurate pre-departure seminars. In terms of addressing this issue, the suggestion by Lusis and Bauder (2008) to develop and provide an accurate and truthful pre-immigration seminar would have been helpful for participants as a tool to prepare themselves on what to expect in their host country. Based on participants' stories, it became apparent that the systemic oppression experienced by the participants is rooted not only in falsities endorsed by the Canadian government, but begins prior to this for participants, in their countries of origin. Oversees employment and immigrant agencies in the Philippines, which fall under the Philippine government such as the Commission on Filipino Oversees, has 
ultimately failed to protect their people against systemic and racial oppression by failing to providing them with accurate information regarding the realities of immigration. Further, the Filipino government plays a role in the oppression of its citizens by failing to screen or monitor the accuracy of advertisements promoting migration for skilled labourers and failing to provide strict guidelines and policies for universities, television and other forms of media to ensure accurate information is delivered to the Filipino public.

Building on this oppression that begins with advertisements in the host countries for skilled migrants, inaccurate pre-departure seminars which are facilitated by the Canadian embassy in the Philippines, subject participants to systemic oppression before immigrants ever set foot in Canada. As several participants reported, given that many immigrants have very limited, if any, networks of support in Canada, they rely exclusively on these seminars and often arrive in Canada completely unprepared for the realities of securing employment. Further, multiple participants endorsed the belief that racial oppression is part of the status quo in the search for employment in Canada. As Martha stated, “ in reality, yeah jobs are available, but not for immigrants...". Martha's statement aptly demonstrates the operationalization of racial oppression in the Canadian labour market experienced by all four participants. This type of oppression has its roots in a reified structure which favours White jobs seekers and excludes racialized skilled job seekers, as was seen by the four internationally educated Filipino social workers who participated in this study as they attempted to seek social work employment in Canada.

Inadequate and insufficient support services were also identified by three of the four participants as one of the systemic barriers they encountered as they attempted to seek social work employment in Canada, as foreign-trained social workers. All four participants endorsed 
difficulty accessing services and navigating the labour market, as is evidenced in their statements below:

Theresa: I went to an employment agency, they advised me to attend resume and cover letter writing seminar but the agency did not help me to get a social work job or any related to my social work job search. If Canada has a specific program to address the needs of immigrant social workers it will be easier to look for a job without going back to school again.

Jude: I did not experience any support from the government after I arrive in this country. So, I would suggest a direct support program for newcomer social workers for example free mentorship program, or a job bank for new comers like gather agencies who are willing to employ foreign-trained social workers.

Ella: The only support I received when I was looking for a job was resume writing. The employment agency did not refer me to any job vacancies. I was very disappointed, I felt like I wasted my time and money for commute.

Martha: So I would say, only volunteering helped me to get in to the field though I am still struggling to get in to the social work setting that I really want.

These three immigrants relied on the support services the government provided during their settlement process, however, based on their statements, the services provided were neither appropriate nor quantifiable in relation to their needs at the time. This example demonstrates the way in which systemic oppression acts as a barrier to employment for Filipino trained social workers seeking employment in Canada. The provision of unequal treatment and support services to racialized job seekers in Canada is yet another example of how the oppression Filipino social workers face in the Canadian job market is systemically produced and reinforced.

As was evidenced by all four participants in this phenomenological research, employment agencies and government support services which are supported to link job seekers up with prospective employers, regardless of race or the origin of employment experience, failed to provide equal services to racialized job seekers and further, worked to reinforce existing systemic barriers to employment. In their narratives, both Jude and Theresa provided 
recommendations on how to improve employment programs for skilled immigrants, which will be discussed later in the implications chapter of this work. Ultimately, insufficient and inaccurate pre-departure seminars and information along with insufficient support services upon arrival in Canada work to systemically recreate and reinforce barriers to employment for foreign-trained social workers, particularly in the context of Filipino social workers migrating to Canada as skilled workers.

\section{Nepotism and a Lack of Connections}

Of the four participants, only Jude and Martha perceived that having a lack of connection to an individual associated with a social welfare agency acted as a systemic barrier to their seeking employment. Nonetheless, it is a significant finding of this work from a phenomenological perspective and, further, from an anti-oppressive perspective. According to both Jude and Martha, obtaining a social work job is not just about your education and experience but also about who you know and who you are connected with. This idea of a lack of connection is ultimately linked to the concept of nepotism in Canadian hiring practices and is representative of a broader understanding of Nepotism in which White, Canadian-trained workers are seen as all being more broadly connected (or seen as 'insiders') and in which Filipino-trained social workers (or any foreign-educated skilled workers) are seen as outsiders.

Below, Martha aptly summarizes what she believes is systemic reality of employment in

\section{Canada:}

Martha: The reality in Canadian labour market is having the right connection inside the agency that can recommend you. It does not matter what you know, it's who you know, which is important to secure a job. Like in the previous agency I worked with, they posted a job vacancy online but that is just for advertisement sake, they already have someone in mind to fill the position. 
As Martha states, "it does not matter what you know, it's who you know" when attempting to secure a job. This longstanding practice of nepotism in hiring practices works to privilege White, Canadian-trained social workers and thus works to recreate and reinforce the marginalization and oppression of Filipino-trained social workers seeking employment in Canada.

Jude goes on to build on Martha's lived experience of nepotism in Canadian hiring practices by discussing his experience of seeking social work employment through connections:

Jude: While working as a maintenance staff, I attended some seminars. There, I met several professionals. I maintained my connections with them as I continued to improve my knowledge and skills. I got the support that I need and I was able to get social work job interviews through these connections.

Both Jude and Martha's statements demonstrate the reality of the Canadian labour market and how it reinforces unjust hiring practices by giving priority to individuals who are informally connected through the perpetuation of nepotism. The social discourses around prioritizing individuals who are known to employers works to directly impact the employability of Filipinotrained social workers who are new to the country and who are still trying to build informal social network. Ultimately, this practice contributes to the exclusion of immigrant social workers and effectively marginalizes them. As a result, many Filipino-trained social workers are forced to acquire menial jobs while building and expanding the social networks necessary to seek skilled employment as social workers. This was evidenced by Jude's above statement about needing to acquire a job in maintenance so that he could afford to take the time to acquire the connections necessary to work in his trained field, as a social worker.

We can extrapolate from the above discussion of social connections that there is an underlying (and oppressive) motive to this nepotistic hiring practice. Ultimately, what Jude and Martha's experiences demonstrate is that the standardization of White norms, values and 
practices plays out such that foreign-trained social workers must prove that they are able to conform to White standards of practice by infiltrating existing Canadian social networks. In order to obtain an employment opportunity, Jude made efforts to expand his network by grappling with and adapting to the dominant race's normative practices. On the hand, Ella and Theresa, through their experiences, state that enrolling in a post-secondary bridging certificate program helped them secure employment by achieving the same underlying goal:

Ella: Without the bridging program from Ryerson, I may not have gotten a social work job. It was a great help, the lectures were very useful and were very needed at that time.

Theresa: The bridging program was my saving grace. I gained a lot of knowledge from the program and I was able to improve my skills that were useful during my social work job search.

The lived experiences and narratives of all four participants in this study reveal the systemic barriers that participants faced in the search for employment, which required them to first forge social networks in a country which was foreign to them.

Ella and Theresa both spoke, above, about the ways in which the system is set up to privilege those who have social connections in Canada, and, further, who conform to White, Canadian standards of social work practice. The narratives of all four Filipino social workers who participated in this research reveal the systemic barriers they have encountered in the Canadian labour market and the ways in which this plays out, one of which is how their lack of connections directly impacts their employability. Further, all four participants expressed dissatisfaction with the support services they have accessed after their arrival to Canada and felt that they should have addressed this lack of connections acting as a barrier to employment. Based on this, it became apparent that this finding (nepotism and a lack of connections) ultimately built on the first major findings of this research: systemic barriers to employment, the 
de-valuation of foreign-obtained social work experience and insufficient/inaccurate pre-departure seminars, information and support services. Thus, nepotism and a lack of social connections although it initially appears to be a less significant finding - is, in reality, the obvious outcome of systemic oppression and is a critical phenomenological finding of this research.

\section{Personal Barriers to Employment:}

Building on the findings above, a process of phenomenological analysis identified that the next significant finding of this research was the revelation that many foreign-trained social workers experienced (what they believed to be) personal barriers to employment. Participants revealed their personal barriers such as lack of knowledge about Canadian resume formatting, attitudes and behaviours, language competency, and insufficient knowledge about the craft, appeared to be significant factors for not being able to secure employment as social workers. These so-called 'personal' barriers are, in reality, a different kind of structural, systemic barrier but are classed separately as they are markedly different from outwardly systemic barriers. These personal barriers are, in fact, barriers to employment due to the systemic racism of the employment process.

According to Krannich and Banis (1998) resumes are the employment applicant's initial communication to their prospective employers and should convey the applicant's qualifications. Further, a resume must create a positive impression of the skills and competency level of the applicant in order to attract potential interviews (Krannich and Banis, 1998). All the participants in this research study assumed that they knew how to create effective resumes for a job search in the Canadian labour market. All four reported that they later found out that Filipino resumes are formatted differently than Canadian resumes, and internalized this as a personal barrier to employment, feeling that they could not write effective resumes. In reality, the formatting 
difference could easily have been addressed in pre-immigration seminars or during the immigration support process. Ultimately, this lack of this knowledge prior to immigration became one of their major struggles in attempting to secure a social work job and has ultimately created a problem of underemployment and unemployment:

Theresa: I went to an employment agency and was told that my resume is not good enough so I decided to attend training for few days on how to write a resume in Canadian format. It didn't help me; the information was inaccurate. A person from another agency looked at my resume and told me that it was wrong so, she helped me revise it.

Jude: I was sending out resumes only to find out that my resume format is not the same as Canadian resume format. To address this concern, I attended a seminar in resume writing which was an advice of an employment counsellor in my volunteer job. Then I started to send out my resumes to those emails that she gave me.

Ella: I didn't receive a single interview because I had a poor resume. I don't know what to put. We have a different resume back home and that is not good enough.

Martha: I was so confident that my resume has all the information that employers need to know about my experience not realizing that my resume is not based on Canadian standard, so that's another factor why I didn't get an interview.

It appears that all four participants internalized oppression by accepting and thinking that their resumes were not good enough to attract employers in the Canadian market.

Building on the issue discussed above, it became evident that resume formatting was evidence of the White norms and standardization of practice which are a key factor in gaining employment in the Canadian labour market. Rather than targeting these differences in standards of practice in pre-immigration seminars, however, it is used as an example of the ways in which foreign-trained social workers do not meet White, Canadian standards of practice. This works to systemically reinforce the individualizing idea of personal barriers to employment which are, in fact, also systemic barriers to employment. This default standard of practice in the Canadian labour market increases the marginalization and social exclusion of Filipino immigrant social 
workers, as is evidenced by all four participants' lived experience as they spoke about their experiences for this study. The notion that they were being judged and discriminated against based on their resume formatting and not their professional experiences and education that could contribute to the organizations successful service delivery, is an example of the way in which systemic oppression works to create the notion of personal barriers to employment.

In the narratives of the four participants in this study, individual attitudes and behaviours also came up as barriers to successful integration into the labour force. Most Filipinos possess an attitude of procrastination, or what they call "mañana habit," and also a colonial mentality. According to Lirio (2010), mañana habit is the tendency to delay things and usually not finishing tasks on the expected time. Two of the participants, Theresa and Martha identified this behaviour as an internal barrier to their success. While the other two participants, Jude and Ella did not mention anything about mañana habit as they were consistent to send out their resumes on a daily basis.

Theresa: I didn't apply for a job right away. I don't know but I just feel lazy to write a resume and cover letter. I felt like I've done that before and I didn't want to do it again during my first two weeks. I kept saying to myself, "I'll do it later."

Martha: During my first six months here in Canada I would admit I procrastinated. I would delay sending out resumes. I told myself "mamaya na or bukas na lang" (later, or tomorrow). I was thinking that with my experience it would be easy to get a social work job so I don't have to worry, I was wrong.

These, too, are systemic barriers to employment which could have been avoided if preimmigration supports were more effective and accurate, as will be identified later in the implications chapter of this work.

The Philippines was colonized for a long time by foreign countries such as Spain, The United States and Japan, and several decades ago that resulted in the cultivation of Filipinos' 
colonial mentality and high regard for anything foreign (Alcuitas, Alcuitas-Imperial, Diocson, Ordinario, 1997; Wells et. al., 2013). Filipino colonial mentality such as "west is the best," "America is a paradise" (Alcuitas, Alcuitas-Imperial, Diocson, Ordinario, 1997) and "Canada being a Graceland" (Wells et. al., 2013) contribute to Filipino immigrants' oppression in ways which are masqueraded as personal barriers to employment. Two of the participants, Jude and Martha, indicated that Filipinos' high regard for anything foreign, especially white, affects their attitudes towards getting a social work job. They identified that their low self-esteem is a result of Filipinos' inherent "colonial mentality" as is evidenced below:

Jude: I would admit during my first few job interviews whether social work or general labour I was delighted I had interviews, I could say I was also overwhelmed. I felt like they are better than me knowing I came from a third world country and this is Canada, one of the top countries in the world. My ideology that Canadians are superiors and as a new comer to this country I felt inferior that somehow made me lose my confidence.

Martha: In my personal belief based on my personal experience, the colonization from our history has a huge effect to my personality because I always look up to people who are White and can speak better English than me. It makes me feel that they are more knowledgeable than me. Later on I realized it is self-sabotaging, I know what I am capable of but I lose my confidence because of my mentality.

Mañana habit and colonial mentality have played a big factor in delaying the participants' entry in to the social work field. Having this behaviour and mentality, participants blame themselves for not gaining social work employment immediately upon migration. Their self-blaming attitude minimizes their confidence and works to contribute to the notion of personal barriers to employment, many of which are also systemic. As expressed by participants above, when they internalized the oppression they experienced in the search for employment, they failed to identify the systemic injustices they have encountered.

Even though English has always been part of the Philippines' educational system, three participants reported that word usage and sentence structure is significantly different in the 
Canadian system and identified this as having an impact on their employability. Based on their experiences, participants noticed that Filipino's often translate sentences or words to English based on how they would say it in daily Filipino usage. These differences in language use and communication structure often result in a misperception that Filipinos or immigrants for whom English is not a first language do not know or speak 'good' English (Basavarajappa \&Verma,1990; Cheng, Spaling \& Song, 2013; Davidson, 2007; Myles, Cheng \& Wang, 2006;

Rudenko, 2012;). Three participants noted this below:

Theresa: I found Filipino traditional English is different from Canadian English, there are times I use words inappropriately. Being aware of that makes me feel conscious (anxious) if another person understands what I am trying to convey. That's why I think it is a barrier to get a social work job because in social work you deal with a lot of people on a daily basis.

Jude: Filipinos are excellent English speakers but in my experience I noticed that word usage is sometimes different. Back home we only pay attention to international English languages testing system courses because we are paying for it, but we are not applying it in our everyday conversation so we don't really have the chance to immerse ourselves and get used to the proper usage.

Martha: When I first came here, I found myself using terminologies and stating sentences the way I say it in "Tagalog" (Filipino national dialect), up to now I still find myself doing that but not as often anymore. I realized it is hard because employers or interviewers are supposed to understand me during the interview, and I know that one wrong word usage may affect my application.

These barriers to employment, as identified by three participants, are portrayed as personal barriers to employment despite their being rooted in systemic barriers.

Two of the participants, Theresa and Martha, emphasized the difference in approach to social work practice in the Philippines and Canada as another significant personal barrier. Even though they came from diverse social work settings back home, they both described Philippine social work practice as generalized social work while Canadian social work practice is much 
more focused on client-centered practice. Given this, they both identified thinking that their knowledge about client-centered practice is insufficient:

Theresa: I worked in a community agency back home for three years then in a hospital for eight years, I can say both are generalized practice. Client-centered approach was taught in school but I didn't get the chance to practice it. So during the interview when I talked about my experience in the Philippines, employers for sure knew that I lack the client-centered practice experience.

Martha: My experience back home was a generalized practice. I know what is clientcentered but I don't have the experience and expertise, so until now I am having difficulty fitting in to the social work setting that I prefer to practice.

Personal barriers for Filipino social workers may vary from individual to individual, however they have one thing in common - they are all rooted in systems which work to oppress foreign-trained social workers in the search for employment. Further, the participants in this study identified these barriers as forms of internalized oppression and one of the central reasons for their inability to secure a social work job. They all endorsed persevering to learn and improve themselves in order to pursue the profession they are passionate about in a Canadian context.

\section{Lack of Knowledge about Canadian Social Legislations and the Social Welfare System in}

\section{Canada}

Three participants in this study - Jude, Ella and Martha - indicated that their lack of specific knowledge about Canadian social policy is one of the factors accounting for their limited success in the job search process. They stated that most of the social work job posts they have encountered require the applicant to have a sound knowledge of Canadian social policy and relevant legislation. For an individual who migrated from another country, it is very difficult to demonstrate to prospective employers that you are equipped with sufficient knowledge to practice in line with agency standards, as is evidenced below: 
Jude: I can contribute my knowledge about international laws but when I landed in this country I would admit, I have no idea about any of their legislations. In my opinion, as a Social Worker it is important that you have a good knowledge about the country's social legislations in order for you to not just abide but also to help your clienteles. In one of my interviews I was asked if I have intensive knowledge about Canadian Mental Health Act. I read a part of it before I went to the interview but honestly my knowledge was vague and that was not enough to convince them that I will be able to address my clients' needs without knowing it by heart.

Ella: In several occasions unfamiliarity with Canadian legislations was a factor for not getting a social work job. I would say, as social workers, we have to familiarize ourselves with Canadian legislations to be an effective practitioner and to promote social justice.

Martha: I had no idea of any Canadian laws. I was lucky I was hired as a volunteer, during my stay with them I slowly had the chance to educate myself with the legislations. In most cases, a fundamental knowledge on Canadian legislations is essential in looking for a social work job. In my experience, when I applied to CAS (Children's Aid Society), court and corrections employers gauged my competence as a worker based on my knowledge about the laws.

Here, we can see how three participants have identified that their insufficient knowledge about specific Canadian legislation became a barrier to their successful social work job search. They have recognized the importance of having familiarity with specific legislations in order to secure a social work job in their prospective social work setting, and yet they were not effectively prepared for this prior to migration.

Three of the participants in this study stated that the bridging program at Ryerson University for Internationally Educated Social Work Professionals introduced them to many of the relevant policies and legislations that are required to practice social work in Canada. Specifically, they were taught about the social welfare system in Canada, and they all recognized this program as one of the best options to educate foreign-trained social workers who would like to pursue their social work career after migration. As they reported, the bridging program at Ryerson University equipped them with the knowledge, attitude and skills needed to embark on a social work career in Canada: 
Theresa: Knowing I have the skills of a good social worker, the bridging program boosted my knowledge and skills needed for a social worker practicing in this country. I learned about the social work system in Canada and I would say it helped me get my present job.

Ella: I never had an interview before I took the bridging program, so after I graduate I had two interviews; and the lectures and skills they taught us in class were useful during my job interviews including the social welfare system in Canada. With the knowledge from the bridging program I learned to navigate the system, I realized if I did not take the bridging I would not be where I am right now.

Martha: Though I was hired at the agency where I first volunteered before I attended the bridging program in my opinion the bridging program gave me all the knowledge and skills I need to practice social work here, the knowledge gave me so much confidence both at work and in my job interviews. The knowledge about the social work system and the community resources are very helpful during job interviews and in practice.

Familiarity with Canadian government legislations and the social welfare system is an important qualification of a social worker competent to effectively deliver services to clients. Participants in this study highlighted the relevance of legislation to the social work profession and to a successful search for employment as a social worker. 


\section{CHAPTER 6. IMLPICATIONS AND CONCLUSION}

This major research paper, although limited in scope, explored the lived experiences of internationally educated, Filipino social work professionals during their integration into the Canadian labour force. The need to pursue this topic stemmed from the recognition of the barriers faced by internationally educated Filipino social workers as they embark on a social work career in Canada. The findings of this project, although limited in scope given the scale of the research, speak to the need to reform the immigration process and supports available to those who have immigrated, as well as to the need for systemic change in the employment process.

One of the first implications which was evident in the findings of this research is the need for social welfare agencies in Canada need to gain a better understanding of the presence and manifestations of systemic racism within the labour market, including the discriminatory hiring practices racialized, skilled immigrants face. This understanding can be utilized to develop effective anti-racism policies within agencies which can work to promote fairness as well as target and reduce the systemic oppression of the newcomer skilled immigrants. Moreover, the federal government needs to consider improving support services for immigrant professionals from pre-departure, arrival to Canada, right up to securing employment. Further, more specific and direct services related to various professions would be highly beneficial. For example, a more progressive approach towards addressing so-called 'personal' barriers to employment is essential if Canada is to target its systemic sites of oppression.

Due to the worsening economic situation in the Philippines, many Filipino social workers are seeking to migrate to a more stable country such as Canada, a decision which is greatly influenced buy the proliferation of advertisements proclaiming the need for skilled workers in Canada. The reality for social workers trained in the Philippines, however is much different, as is 
shown in this work. Given that social work is a profession which promotes social justice, equality and respect for diversity, it is a particularly poor indicator that the barriers to social work employment are so entrenched in systemic racism and the privileging of White, Canadian standards of practice. The oppression Filipino social workers face when seeking employment in Canada merely begins with the hiring process. As a result of their experiences, the four participants in this study call for more direct and accurate support services to better mitigate the systemic barriers to employment faced by foreign-trained social work professionals.

This research reported on the effects of the hardships all four participants have encountered during the process of embarking on a social work career in Canada. It is essential to the social justice motives of this research that the narratives of Filipino social workers be analyzed through an anti-racism framework. The hope of this research is to create a space for the discussion of systemic barriers to employment for foreign-trained social work professionals and further, to utilize anti-racist theory to delve into the oppression it creates for this population. The implications of this conversation, though limited due to the scope of the research, are critical to the broader social justice movement which seeks to challenge the systemic barriers to employment faced by foreign-trained social workers seeking employment in Canada.

The labour market and the social welfare system in Canada are all based on Canadian culture and norms, despite the fact that Canada is a country of diverse cultures. This creates a power dynamic in which the White, dominant majority are in a position of power over immigrants and racialized individuals, who subsequently become powerless. A particularly strong example of this is the hiring stipulation of 'Canadian experience' which systemically excludes immigrants from participation in the skilled labour force. This is particularly apparent in social work, as is evidenced by both the literature reviewed for this research, along with the 
participants interviewed. Ultimately, all four participants expressed their feeling of degradation after non-recognition of their foreign-obtained professional experience and endorsed feeling that systemic and racist factors were at play in their experiences.

This study also revealed that internationally-educated Filipino social workers' personal barriers contributed to their inability to secure a social work job. Upon further analysis, it was demonstrated that this is rooted in the systems which fail to effectively prepare Filipino social workers (and other professionals) for the Canadian job market. This demonstrates a need for more effective services both prior to migration and upon arrival in Canada. Given that the participants in this research reported that their knowledge, skills, and personal improvement gained from Ryerson University's bridging program for internationally educated social workers was critical to their job search, it is a finding of this research that a similar program is needed for all migrants, prior to their immigration to Canada.

Given that all four participants in this research expressed disappointment with the inadequate supports, programs and services prior to departure from their home country and upon arrival to Canada, the need for this system to be overhauled is one of the most central implications of this research. In conclusion, this study has demonstrated the systemic factors at play in the immigration process and subsequent job search for Filipino-trained social workers and outlined some of the implications for the Canadian government. Further, it has created a space where the narratives and lived experiences of individuals who have experienced this process are privileged as fact and as indicators of the need for systemic change. 


\section{APPENDIX A. CONSENT AGREEMENT}

\section{RYERSON}

UNIVERSITY

\section{Ryerson University \\ Consent Agreement}

You are being invited to participate in a research study. Please read this consent form so that you understand what your participation will involve. Before you consent to participate, please ask any questions to be sure you understand what your participation will involve.

Challenges of Internationally Educated Filipino Social Workers: Implication to Social Work Practice in Canada

This research study is being conducted by Roshena Grace Hernandez for a Major Research Paper as a partial completion of the Master of Social Work degree. The result of the study will contribute to a Major Research Project. This research is under the supervision of Dr. Henry Parada, from School of Social Work at Ryerson University.

If you have any questions or concerns about the research, please feel free to contact Roshena Grace Hernandez at rhernandez@ ryerson.ca; or Dr. Henry Parada at (416) 979 - 5000 ext.6223, hparada@ryerson.ca.

PURPOSE OF THE STUDY: The study is designed to explore the lived experiences of internationally educated Filipino Social work professionals to identify the challenges they face to start a social work career in Canada.

This research will involve five participants who are Filipino social work professionals who have obtained education and professional experience in the Philippines. All participants will have immigrated to Canada between five and ten years ago, have had their credentials assessed, and have been registered with Ontario's regulatory body.

WHAT YOU WILL BE ASKED TO DO [OR] WHAT PARTICIPATION MEANS: If you volunteer to participate in this study you will be expected to attend one session of 45-60 minutes of face-to-face interview.

Open-ended questions will be provided in order for you to freely share your lived experiences.

Questions will focus on the barriers that you encounter during your post-migration to the country, and your experiences on integration to social work profession. Sample questions are: 
1. What were your expectations prior to coming to Canada in terms of professional opportunities?

2. Did you attend an information session regarding Canadian employment opportunities/ labour market trends?

3. What was your experience upon trying to integrate in to labour force?

Demographic data that will be collected include: name, gender, length of stay in the country, educational level, E-mail address, and telephone number.

If you would like to request a copy of the final major research project, a copy of the material will be sent to your email.

POTENTIAL BENEFITS: You will have the opportunity to be heard through revelation of your experiences; and the findings of this study may not directly benefit you, but the final findings of this research may contribute information to future research.

I cannot guarantee, however, that you will receive any benefits from participating in this study.

WHAT ARE THE POTENTIAL RISKS TO YOU AS A PARTICIPANT: There is a minimal risk involved in the study. Due to the exploration of your lived experiences, questions may be personal in nature, and may reflect on unpleasant memories during the interview. In the event you feel any discomfort you may skip answering a question or stop participation, either temporarily or permanently.

CONFIDENTIALITY: All identifying information you provide during the interview will be treated confidential unless you specifically indicate your consent. Your name will not appear in any report or publication of the research. Pseudonyms or codes will be used as your identifying information to your data during the interview, and on the written report of findings to ensure confidentiality.

Data will be collected through an audio-recorded face-to-face interview. Your data will be securely stored in a passcode-protected recorder, and will be transferred to a passwordprotected computer. Only the researcher and the supervisor will have the access to the information. The data will be stored during the duration of the study and expected to safely destroy at the end of the study (August 28, 2015), or in the event you choose to stop participating, and would like to not have your data included in the study.

INCENTIVES FOR PARTICIPATION: The participant will not be paid to participate in this study.

\section{COMPENSATION FOR INJURY:}

By agreeing to participate in this research, you are not giving up or waiving any legal rights in the event that you are harmed during the research. 


\section{VOLUNTARY PARTICIPATION AND WITHDRAWAL:}

Participation in this study is completely voluntary. You can choose whether to be in this study or not. If any question makes you uncomfortable, you can skip that question. You may stop participating at any time. Please be reminded that there will be no incentives and reimbursements to be given as described above. If you choose to stop participating, you may also choose to not have your data included in the study. Your choice of whether or not to participate will not influence your future relations with Ryerson University or the investigator Roshena Grace Hernandez involved in the research.

QUESTIONS ABOUT THE STUDY: If you have any questions about the research now, please ask. If you have questions later about the research, you may contact:

Roshena Grace Hernandez, Master of Social Work Student Ryerson University at (647) 269 -4680, rhernandez@ryerson.ca; or Dr. Henry Parada at (416) 979 - 5000 ext. 6223, hparada@ryerson.ca.

This study has been reviewed by the Ryerson University Research Ethics Board. If you have questions regarding your rights as a participant in this study please contact:

Research Ethics Board

c/o Office of the Vice President, Research and Innovation

Ryerson University

350 Victoria Street

Toronto, ON M5B 2K3

416-979-5042

rebchair@ryerson.ca 


\section{APPENDIX B. CONFIRMATION OF AGREEMENT}

\section{RYERSON}

UNIVERSITY

Challenges of Internationally Educated Filipino Social Workers: Implication to Social Work Practice in Canada

\section{CONFIRMATION OF AGREEMENT:}

Your signature below indicates that you have read the information in this agreement and have had a chance to ask any questions you have about the study. Your signature also indicates that you agree to participate in the study and have been told that you can change your mind and withdraw your consent to participate at any time. You have been given a copy of this agreement.

You have been told that by signing this consent agreement you are not giving up any of your legal rights.

Name of Participant (please print)

Signature of Participant

Date

I agree to be audio-/video-recorded for the purposes of this study. I understand how these recordings will be stored and destroyed.

Signature of Participant

Date 


\section{APPENDIX C. RECRUITMENT ADVERTISMENT}

\section{RYERSON UNIVERSITY}

Do you have the following qualifications?

- A Filipino social work professional

- Obtained education and professional experience in the Philippines

- Have immigrated to Canada between five and ten years ago

- Have had your credentials assessed, and

- Have been registered with Ontario's regulatory body

If your answer is yes, you might be interested to participate in a study entitled

“Challenges of Internationally Educated Filipino Social Workers: Implication to Social Work

\section{Practice in Canada."}

The participation in this study is completely voluntary, and you will not be paid to participate in this study. As a participant in this study you would be asked to attend a 45 to 60minutes of audio-recorded one-on-one face-to-face interview at the Ryerson University Library Room at Victoria Street Toronto, Ontario.

All identifying information you provide during the interview will be treated confidential unless you specifically indicate your consent. Your name will not appear in any report or publication of the research. Pseudonyms or codes will be used as your identifying information to your data during the interview, and on the written report of findings to ensure confidentiality.

For more information about this study, or to volunteer to participate for this study, please contact Roshena Grace Hernandez, School of Social Work Ryerson University at 647-269-4680 or email: rhernandez@ryerson.ca. 


\section{APPENDIX D. ETHICS CERTIFICATE}

\section{RYERSON UNIVERSITY \\ RESEARCH ETHICS BOARD}

To: Roshena Grace Hernandez

MSW student

Re: REB 2015-044: Challenges of Internationally Educated Filipino Social Work Professionals: Implication to Social Work Practice in Canada

Date: March 9, 2015

\section{Dear Roshena Grace Hernandez,}

The review of your protocol REB File REB 2015-044 is now complete. The project has been approved for a one year period. Please note that before proceeding with your project, compliance with other required University approvals/certifications, institutional requirements, or governmental authorizations may be required.

This approval may be extended after one year upon request. Please be advised that if the project is not renewed, approval will expire and no more research involving humans may take place. If this is a funded project, access to research funds may also be affected.

Please note that REB approval policies require that you adhere strictly to the protocol as last reviewed by the REB and that any modifications must be approved by the Board before they can be implemented. Adverse or unexpected events must be reported to the REB as soon as possible with an indication from the Principal Investigator as to how, in the view of the Principal Investigator, these events affect the continuation of the protocol.

Finally, if research subjects are in the care of a health facility, at a school, or other institution or community organization, it is the responsibility of the Principal Investigator to ensure that the ethical guidelines and approvals of those facilities or institutions are obtained and filed with the REB prior to the initiation of any research.

Please quote your REB file number (REB 2015-044) on future correspondence.

Congratulations and best of luck in conducting your research.

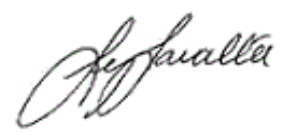

Lynn Lavallée, Ph.D.

Chair, Research Ethics Board 


\section{APPENDIX E. INTERVIEW GUIDE}

\section{RYERSON UNIVERSITY}

RESEARCH ETHICS BOARD

\section{Interview Guide}

1. How long have you been in Canada?

2. What were your expectations prior to coming to Canada in terms of the settlement process?

3. What were your expectations prior to coming to Canada in terms of professional opportunities?

4. Did you attend an information session regarding Canadian settlement process?

5. Did you attend an information session regarding Canadian employment opportunities/ labour market trends?

6. Did you plan to pursue a social work career upon arrival to Canada?

7. If yes, what were the steps you have taken to achieve your goal?

8. If not, what was your plan?

9. What was your experience upon trying to integrate to labor force? 


\section{REFERENCES}

Alboim, N., Finnie, R., \& Meng, R. (2005). The discounting of immigrants' skills in Canada: Evidence and policy recommendations. Choices, 11(2), 1-26.

Alcuitas, H., Alcuitas-Imperial, L., Diocson, C., Ordinario, J. (1997). Trapped "Holding on to the Knife's Edge.” Retrieved from http://fredacentre.com/wp content/uploads/2010/09/Philippine-Women-Centre-of-BC-1997.pdf

Atkinson, R., \& Flint, J. (2001). Accessing hidden and hard-to-reach populations: Snowball research strategies. Social research update, 33(1), 1-4.

Basavarajappa, K., \& Verma, R. (1990). Occupational composition of immigrant women. Ethnic demography, Canadian immigrant, racial and cultural variations, 297-311.

Baldacchino, G., Chandrasekere, S., \& Saunders, P. (2007). Internationally Educated Health Professions in Atlantic Canada. Canadian Issues, 104-107.

Biernacki, P., \& Waldorf, D. (1981). Snowball sampling: Problems and techniques of chain referral sampling. Sociological Methods \& Research, 10(2), 141-163.

Bidhendi, E. (2006). Employment facilitation programs for professional immigrants in the Greater Toronto Area: Surveying participants' opinions about the programs. (Order No. NR39798, University of Toronto. Retrieved from http://ezproxy.lib.ryerson.ca/login?url=http://search.proquest.com/docview/34378760

Bloom, M. \& M. Grant. (2001). Brain Gain. The Economic Benefits of Recognizing Learning Credentials in Canada. Ottawa: Conference Board of Canada.

Canadian Association of Social Workers. (n.d.). International Assessment of Credentials. Retrieved from http://www.casw-acts.ca/en/what-social work/international assessment credentials. 
Cheng, L., Spaling, M. A., Song, X., Ebrary CEL - York University., CERIS., \& Canadian Electronic Library (Firm). (2013). The role of testing in professional certification for newly arrived foreign trained professionals to Canada. Toronto, Ont.: CERIS - The Ontario Metropolis Centre.

Chiswick, B. \& Miller, P. (2003). Immigrant earnings: Language skills, linguistic concentrations and the business cycle. Journal of Population Economics, 15(1), 31-57.

Conference Board of Canada. (2004). The Voices of Visible Minorities: Speaking Out on Breaking Down Barriers. Briefing, Human Resource Management.

Creswell, J. W. (2007). Qualitative inquiry and research design: Choosing among five traditions.

Creswell, J. W. (2005). Educational research: Planning, conducting, and evaluating quantitative and qualitative research (2nd ed.). Upper Saddle River, NJ: Pearson.

Creswell, J. W. (2012). Qualitative inquiry and research design: Choosing among five approaches. Sage.

Davidson, M. (2007). Bridging The Gap: A Study Of The Ryerson University, Chang School of Continuing Education, Internationally Educated Social Work Professionals Bridging Program.

Dei, G.S. (1996). Anti-racism Education: Theory and practice. Halifax: Fernwood.

Fang, C. (2012). Foreign Credential Assessment and Social Work in Canada. Retrieved from http://www.saws.ca/council/FQR-Report 2012-Final.pdf.

Faulkner, S., \& Faulkner, C. (2 ed.). (2014). Research methods for social workers: a practice based approach. Chicago, IL: Lyceum Books, Inc. 
Galabuzi, G.E. and Teelucksingh, C. (2005). Working Precariously: The impact of race and immigrants status on employment opportunities and outcomes in Canada. Toronto: Canadian Race Relations Foundation. www.crr.ca/diversfiles/en/publications/reports/publWorkingPrecariously.pdf

Gawronski, E. (2001). No Canadian Experience-No Job. Fact or Myth? A qualitative inquiry of newcomers' perceptions and experiences with the labour market. Department of Curriculum, Teaching and Learning. Ontario Institute for Studies in Education of the University of Toronto.

George, U., \& Chaze, F. (2012). Credential assessment of internationally trained profession. How effective is the process for the purpose of securing employment? Journal of Immigrant \& Refugee Studies, 10(1).

Government of Canada. (2006). Forging Our Legacy: Canadian Citizenship and Immigration, 1900-1977. Retrieved from http://www.cic.gc.ca/english/resources/publications/legacy/chap-6.asp

Government of Canada. (2013). Learn about credential assessment. Retrieved from http://www.cic.gc.ca/english/newcomers/credentials.

Government of Canada. (2015). Six Selection Factors - Federal Skilled Workers. Retrieved from http://www.cic.gc.ca/english/immigrate/skilled/applyfactors.asp

Gou, Y. (2009). Racializing immigrant professionals in an employment preparation ESL program. Cultural and Pedagogical Inquiry, 1(1), 40-44. Retrieved from http://socialiststudies.com/index.php/cpi/article/viewFile/7119/5862 
Grant, P. R. (2005). The devaluation of immigrants' foreign credentials: The psychological impact of this barrier to integration into Canadian society. Prairie Centre of Excellence for Research on Immigration. Saskatchewan: University of Saskatchewan.

Grant, H. \& Sweetman, A. (2004). Introduction to economic and urban issues in Canadian immigration policy. Canadian Journal of Urban Research 13 (1), 1-24.

Gray, M. (2005) Dilemmas of international social work: Paradoxical processes in indigenization, imperialism and universalism. International Journal of Social Welfare, 14,230-237.

Gray, J. (2007). Reconsidering voice. Qualitative Social Work, 6(4), 411-430.

Groenewald, T. (2004). A phenomenological research design illustrated.

Hall, R., \& Sadouzi, T. (2010). The value of "experience" and the labour market entry of new immigrants to Canada. Canadian Public Policy, 36, 181-198. doi:10.3138/cpp.36.2.181.

Humphrey, C. (2007). Insider-outsider: Activating the hyphen. Action Research, 5(1), 11-26. Labour Program. (2013). Designated Group Profiles. 2006 Employment Equity Data Report. Retrieved from http://www.labour.gc.ca/eng/standards_equity/eq/pubs_eq/eedr/2006/ profiles/page09.shml

Lirio, P. (2010) "West meets Southeast." The Multinational Enterprise in Developing Countries. 33, p.38

Lusis, T., Bauder, H., \& CERIS. (2008). "Provincial" immigrants: The social, economic, and transnational experiences of the Filipino Canadian community in three Ontario second tier cities. Toronto: CERIS.

Man, G. (2004). Gender, work and migration: Deskilling Chinese immigrant women in Canada. Women's Studies International Forum, 27, 135-148. 
Moustakas, C. (1994a). Phenomenological research methods. Thousand Oaks, CA: Sage.

Moustakas, C. (1994b). 3 Phenomenology and Human Science Inquiry. In Phenomenological research methods. (pp. 43-68). Thousand Oaks, CA: SAGE Publications, Inc. doi: http://dx.doi.org/10.4135/9781412995658.d5

Myles, J., Cheng, L., \& Wang, H. (2006). Teaching in elementary school: Perceptions of foreign trained teacher candidates on their teaching practicum. Teaching and Teacher Education, $22,233-245$.

Neuman, W. L. (2003). Social research methods: Qualitative and quantitative approaches $\left(5^{\text {th }}\right.$ ed.). Boston, MA: Pearson Education.

Neuman, W.L. (2006). Social research methods: qualitative and quantitative approaches. Boston: Toronto: Pearson/Allyn and Bacon.

Ngo, H. V., \& David E. (2006). Professional re-entry for foreign-trained immigrants. Journal of International Migration and Integration, 7(1), 27-51.

Novak, L., \& Chen, C. (2013). Career development of foreign trained immigrants from regulated professions. International Journal for Educational and Vocational Guidance, 13(1), 5 24.doi:10.1007/s10775-012-9235-6.

Ontario College of Social Workers and Social Service Workers. (2015). International Degree. Retrieved from http://www.ocswssw.org/registration-section/social-work-applicants/sw intl-degree/

Padgett, D. K. (2008). Qualitative methods in social work research (Vol. 36). Sage.

Policy Round Table Mobilizing Professions and Trades. (2005). Smart Settlement: Current Dispersion Policies and a Community Engagement Model for Sustainable 
Immigrant Settlement in Ontario's Settlement Communities. Toronto: A PROMPT Discussion Paper.

Pon, G. (2009). Cultural competency as new racism: An ontology of forgetting. Journal of Progressive Human Services, 20(1), 59-71.

Pon, G. (2004). Anti-racism education in the cosmopolis: Reflection by Chinese Canadian elites about race and racism (Order No. NQ99223). Available from ProQuest Dissertations \& Theses A\&I; ProQuest Dissertations \& Theses Global. (305117773). Retrieved from http://ezproxy.lib.ryerson.ca/login?url=http://search.proquest.com/docview/305117773? ccountid=13631

Pon, G., Gosine, K., \& Phillips, D. (2011). Immediate response: Addressing anti-Native and anti-black racism in child welfare]. International Journal of Child, Youth, and Family Studies, 3 \& 4: 385-409.

Potts, K. \& Brown, L. (2005). Becoming an anti-oppressive researcher. In L. Brown \& S. Strega (eds.), Research as Resistance, 255-286. Toronto: CanadianScholars' Press.

Pullen- Sansfaçon, A., Brown, M. A., \& Graham, J. (2012). International migration of professional social workers: toward a theoretical framework for understanding professional adaptation process. Social Development Issues. 34(2), 37-50.

Pullen Sansfaçon, A., Brown, M., Graham, J., \& Dumais Michaud, A. (2014). Adaptation and Acculturation: Experiences of Internationally Educated Social Workers. International migration and integration. doi:10.1007/s12134013-0288-2 [cite the specific volume and issue, page numbers of the article]

Razack, N. (2002) Transforming the Field: Critical Anti-racist and Anti-oppressive Perspectives for the Human Services Practicum. Halifax: Fernwood Publishers 
Reitz, J.G. (2001). Immigrant success in the knowledge economy: Institutional change and the immigrant experience in Canada, 1970-1995. Journal of Social Issues, 57(3), 579-613. Rudenko, M. (2012) Canadian experience' and other barriers to immigrants' labour market integration: Qualitative evidence of newcomers from the former Soviet Union

Sakamoto, I., Ku, J., \& Wei, Y. (2009). The deep plunge: Luocha and the experiences of earlier skilled immigrants from mainland China in Toronto. Qualitative Social Work, 8, 427 447.

Shank, G. (2006). Six alternatives to mixed methods in qualitative research. Qualitative research in psychology, 3(4), 346-356.

Sakamoto, I., Jeyapal, D., \& Bhuyan, R. (2013). An Overview of Discourses of Skilled Immigrants and "Canadian Experience": An English-Language Print Media Analysis. Toronto, ON, CAN: CERIS The Ontario Metropolis Centre.

Samuel, E. (2009). Acculturative stress: South Asian immigrant women's experiences in Canada's atlantic provinces. Journal of Immigrant \& Refugee Studies, 7(1), 16-34. doi:http://dx.doi.org/10.1080/15562940802687207

Service Canada. (2011) Social Work Unit Group 4152 Data. Retrieved from http://www.servicecanada.gc.ca/eng/qc/job_futures/statistics/4152.shtml\#type

Sinacore, A., Mikhail, A. M., Kassan, A., \& Lerner, A., (2009) Cultural transitioning of Jewish immigrants: Education, employment and integration. International Journal of Educational Volational Guidance, 9, 157-176. doi:10.1007/s10775-009-9166-z. 
Statistics Canada. (2008). Census Snapshot - Immigration in Canada: A Portrait of the Foreign born Population, 2006 Census. Retrieved from http://www.statcan.gc.ca/pub/11-008 x/2008001/article/10556-eng.htm

Statistics Canada. (2010). Canada's Ethnocultural Mosaic, 2006 Census: Definitions. Retrieved from https://www12.statcan.gc.ca/census-recensement/2006/as-sa/97-562/note-eng.cfm

Statistics Canada. (2013). Migration: International, 2010 and 2011. Retrieved from http://www.statcan.gc.ca/pub/91-209-x/2013001/article/11787-eng.htm

Teo, S. (2007). Vancouver's newest Chinese diaspora: settlers or “immigrant prisoners"? GeoJournal, 68, 211-222.

Thobani, S. (2000). Closing ranks: Racism and sexism in Canada's immigration policy. Race \& Class, 42(1), 35-55. doi:10.1177/030639600128968009

Thompson, E. N. (2000). Immigrant occupational skill outcomes and the role of region-oforigin specific human capital. Hull, Quebec: Applied Research Branch, Human Resource Development Canada.

Türegün, A. (2011). What Do Immigrants Do When They Can't Practise Their Professions? Immigrant Professionals in the Ontario Settlement Service Sector. Toronto, ON, CAN: CERIS - The Ontario Metropolis Centre.

Watt, D., \& Bloom, M. (2001). Exploring the learning recognition gap in Canada. The Conference Board of Canada.

Wells, L., Hurlock, D., Antonio, M., Lantion, V., Abboud, R. Claussen, C., Lorenzeti, L. (2013). A Context of Domestic Violence: Learning for Prevention from Calgary Filipino 
Community. International Journal of Children, Youth \& Family Studies. 1: 147-165.

Retrieved from 11851-7618-1-PB-2.pdf

Yee, J. Y., Wong, H. W., Janczur, A., \& CERIS. (2007). Examining systemic and individual barriers experienced by visible-minority social workers in mainstream social service agencies: A community project. Toronto: CERIS.

Young, I. M. (2000). Five faces of oppression. In Reading for Diversity and Social Justice. New York: Routledge. 